

The Last Tribute to Isabella of Bourbon at Salamanca Author(s): Emilia Montaner

Source: Journal of the Warburg and Courtauld Institutes, Vol. 60 (1997), pp. 164-193 Published by: The Warburg Institute Stable URL: http://www.jstor.org/stable/751228

Accessed: 25-10-2016 16:48 UTC

JSTOR is a not-for-profit service that helps scholars, researchers, and students discover, use, and build upon a wide range of content in a trusted digital archive. We use information technology and tools to increase productivity and facilitate new forms of scholarship. For more information about JSTOR, please contact support@jstor.org.

Your use of the JSTOR archive indicates your acceptance of the Terms \& Conditions of Use, available at http://about.jstor.org/terms

The Warburg Institute is collaborating with JSTOR to digitize, preserve and extend access to Journal of the Warburg and Courtauld Institutes 


\section{THE LAST TRIBUTE TO ISABELLA OF BOURBON AT SALAMANCA}

\section{Emilia Montaner}

7 he ceremonies with which Spanish cities marked the death of a member of the royal family were among the most truly Baroque manifestations of seventeenthcentury culture, combining, as they did, into a seamless whole a complex web of reference to diverse areas of knowledge. Like rhetoric, drama and the treatises on spiritual exercises, they sought to involve the emotions, to provoke particular reactions -in this case respect for the established order and a consciousness of that feeling of 'más vivo desengaño' ('most acute disillusionment'), to use an expression of the period for a sentiment which combined reflection on the frailty of life with contempt for things of the world. Hieroglyphs and allegorical poetry, composed especially for such occasions and often selected through public competitions, contributed much to emblematic imagery, and ephemeral constructions played their part in the evolution of artistic forms. Official descriptions of the ceremonies, designed to leave a record for posterity and to document a city's loyalty to the crown, came to constitute a literary genre of ceremonial accounts known as Libros de Relaciones de honras. Historical circumstances and developments in political thought, as well as the special characteristics of the deceased, and the ingenuity of the institutions responsible for the organisation of the ceremonies all had their part to play, and deserve to be studied for their influence and effect. ${ }^{1}$

Two cities were particularly important in the context of such celebrations: Madrid, with the court and its artists, and Salamanca, with its university and scholars. Although the modest resources of Salamanca did not make it possible to engage famous craftsmen, let alone run to the expense of ambitious settings, the university could offer a unique architectural framework and a matchless array of talented scholars ready to devise symbolic programmes.

Paying homage to the memory of monarchs was a demonstration of loyalty to monarchy itself. Such was the case for the commemoration of Isabella of Bourbon, wife of Philip IV, who died on 6 October 1644 in the Alcázar in Madrid. When, therefore, on the banks of the Tormes, the royal despatch announced her death, the most

\footnotetext{
1 Many publications have dealt with royal funeral rites celebrated in Spain from diverse perspectives; to present a detailed list of these would go beyond the aims of this article. See in particular J. Varela, La muerte del Rey, Madrid 1990 (dealing with the origin and development of funeral etiquette); V. Soto Caba, Catafalcos reales del barroco español. Un estudio de arquitectura efimera, Madrid 1991; S. Orso, Art and Death at the Spanish Habsburg Court: The Royal Exequies for Philip IV, Columbia 1989. With respect to Salamanca prior to the period studied in this article, see the Libros de Relaciones of the exequies of Margaret of Austria and Philip III: B. de Céspedes,
}

Relación de las honras que hizo la Universidad de Salamanca a la Majestad de la reina $D^{a}$ Margarita de Austria..., Salamanca 1611; and Exequias, túmulo y pompa fumeral que la Universidad de Salamanca hizo en las honras del rey don Felipe III, Salamanca 1621. E. Montaner, 'Exequias Reales y pompa funeral', Salamanca y su proyección en el mundo, ed. J. A. Bonilla, Salamanca 1992, pp. 533-59, studies the formal and symbolic aspects of both catafalques. The funerals of the Emperor Charles V and of Philip II were probably taken as the model for the funeral ceremonies of the 17 th century (ibid., p. 534 n. 3). 
significant corporations of Salamanca-town council and parish clergy, as represented by the Real Clerecía de San Marcos ${ }^{2}$-and the university ordered solemn funeral rites for the queen's soul. These were to be carried out with all due ostentation, even if the costs should exceed the funds of the various institutions, and in spite of the sanctions which, since the days of the Catholic Monarchs, had limited expenditure on mourning.

The first step was to meet and appoint committees to oversee the preparations. Perhaps their most formidable task, given the shortage of funds, was the collection of material resources. Donations had to be requested and money borrowed; personal possessions of the organisers were even put up as security. The town council applied for a loan of 3,000 ducats to erect a cenotaph and even spoke of mortgaging the estates of the caballeros regidores until such time as expenses should be authorised ('entretanto que se saca facultad para el gasto'). The university raised 2,500 ducats by leasing some estates, and a further 1,500 were contributed by Canon Zamora from the Cathedral of Coria. $^{3}$

The committees also had to find suitable locations for the event. The elegant transept of the Gothic cathedral was chosen for the funeral ceremonies of the town council while the Royal Clergy had their circular Romanesque chapel. The courtyard of the Escuelas Mayores provided an incomparable setting for the rites conducted by the university. The design for the catafalque, as well as the committee for the decorations, and the sermon and funeral oration were selected by public competition. The city's celebrated monasteries combined with the university to provide learned collaborators. $^{4}$

As soon as the date had been set, for 21 December 1644, competitions were announced for hieroglyphs and poetry in Latin and Castilian. The university contest required two versions of each item submitted, one in small format to be examined by the panel of judges, and a larger and more carefully prepared one which, if successful, would decorate the catafalque or the walls of the cloister. ${ }^{5}$ The competitors, besides receiving the recognition of having their compositions published in the official record of the exequies, were also awarded objects appropriate to their age and station: rings, gold chains, fine gloves, stockings or collections of books. Don Luis Venegas de Figueroa, maestrescuela of the university and bishop elect of Almería, was one of the winners, as were Don Manuel Francisco de Moscoso y Córdoba, Don Sebastian Malo and the Jesuit Diego de Orozco. The epitaphs of Juan de Solorzano (fifth child of Don Juan Solorzano Pereira, the famous jurist and former professor of the university), ${ }^{6}$ of Don

\footnotetext{
2 This was an association with medieval origins (first documented in 1202), founded to protect the interests and rights of the clergy and maintained by tithes and donations. Placed under royal protection, it re-emerged during the reign of Philip II; see A. Riesco Terrero and J. Alvarez Villar, La iglesia románica y la real clerecía de San Marcos en Salamanca, 2nd edn, Salamanca 1990, pp. 52, 77,81 .

3 Town council: Salamanca, Archivo Municipal, Libro de Consistorio, no. 28, fol. $441^{\mathrm{r}}$. University: Archivo de la Universidad de Salamanca [hereafter AUS], 113, fol. 79r.

4 AUS, 113 , fol. $4^{\mathrm{r}}$. With respect to the university obsequies, the rector Don Fernando Bazán, grandson of the Marquis of Santa Cruz, delivered the funeral oration and the Jesuit Father Francisco Pimentel, son of the Count of Benavente, preached.

5 The conditions of the competition were displayed under a velvet canopy on the door of the chapel of San
}

Jerónimo: see AUS, 113 , fol. $66^{\mathrm{v}}$; ibid., 1329, fol. $45^{\mathrm{r}}$ The epigrams for the sepulchre, in Latin or Greek, could be no longer than eight distychs. Acrostics whose first letters spelled the name of the deceased queen were also accepted. The winning compositions can be found in the Relaciones de la funeral (for which see below and n. 8), fols $79^{\mathrm{v}}-114^{\mathrm{r}}$. On the university contests see J. Simón Díaz, 'La poesía mural. Su proyección en Universidades y colegios', Estudios sobre el siglo de oro, homenaje al profesor F. Yndurain, Madrid 1984, pp. 481-97.

6 The celebrated jurist Don Juan de Solorzano y Pereira was born around 1575 and came to Salamanca in 1587, where he graduated in canon and civil law, becoming Professor of Law in 1606. He then left the university to begin a rising intellectual and political career. The author of Politica Indiana among other treatises, he belonged to the Consejo de las Indias y de Castilla. He had eight children, among whom Juan, a 
Alvaro de Villegas (a member of the college of San Bartolomé) and those composed by the clerics Fray Agustín de Madrid, Juan de Toledo and Gonzalo de Ojea received special mention.

The town council could not afford to finance even a short publication recording its obsequies. The Clergy of San Marcos at least managed to subsidise the publication of a brief summary. ${ }^{7}$ In the case of the university, however, a description of the honours written by Luis Félix de Lançina y Ulloa appeared at Salamanca under the title Relación de la funeral pompa en las honras que hizo la muy insigne Universidad de Salamanca ... a la buena memoria de la reina ... Isabel de Borbón ${ }^{8}$ and this provides a detailed account of the events. The book cannot compare, as an object, with the elegantly printed works produced at court circles, but it is outstanding in its narrative skill and descriptive rigour. The text is enriched with a multitude of learned quotations provided by the scholar who devised the symbolic programme (to which Lançina no doubt added some of his own: see Appendix Ia) and with transcriptions of the epitaphs and panegyric poems. Within the limitations of its genre, as an apologetic treatise, Lançina displays a personal style marked by subtly veiled political opinions, frequent bursts of virtuoso skill and a shrewd sense of humour that is altogether surprising in the solemn context (see Appendix Id). Thus, the literary quality of the Relacion makes up for the book's poor typography and lack of illustrations and even for the pedantry of its content, predictable in an academic exercise of this sort.

Since they were operating in a consecrated space, the town council and the clergy of San Marcos restricted their decorative interventions to the erection of the catafalque and the covering of walls or vaults with crêpe and heraldic motifs. Otherwise virtually the only expenses were payments to singers and musicians, and for torches and white candles. ${ }^{9}$ By contrast, the organisers of the university's commemoration, who had been chosen at a plenary session of the academic senate from among the professors of the different faculties, initially prepared an extraordinary, complex pageant which, since it went far beyond the practical possibilities, was rejected by those whoin a clear-headed spirit of criticism unexpected at the period-suggested banishing 'the laborious and empty lavishness of pomp' ('la penosa y vana suntuosidad de la pompa'); in their view good works, masses and prayers would be better for the soul of the departed queen. ${ }^{10}$ This quarrelsome group, apparently headed by Sánchez Randoli, Vespers Professor of Canon Law, argued against the proposal that the university strive to surpass the expense of previous funeral ceremonies: there was, after

member of the Arzobispo Fonseca College in Salamanca, was mayor of Hijosdalgo in the chancery of Granada. This Juan was a knight of the order of Calatrava, and inherited his father's well-endowed library 'para estudio y no para su venta'. See the introduction by M. A. Ochoa Brun to Juan de Solorzano y Pereira, Politica Indiana, Madrid 1972, pp. xiii-xvii.

7 F. de Arando y Mazuelo, Honras que la capilla real de San Marcos... celebró a la majestad catholica de la reina..., Salamanca 1644 (the National Library in Madrid has a copy: VE 176 no. 11). This modest leaflet consists of a dozen or so unnumbered pages. The author was rector of the San Bartolomé College and Professor of Philosophy at the university.
${ }^{8}$ All quotations from the Relacion in this article are taken from the the copy in the National Library in Madrid, no. 3/60263. The Relación is catalogued by A. Palau y Dulcet, Manual del librero hispanoamericano, Barcelona 1954, no. 130927.

9 Arando y Mazuelo (as in n. 7): 'acompañaban la real tumba... tanto número de hachas y velas de cera blanca y tan entoldada y cubierta de luto toda la iglesia ... con muchos escudos de armas reales... a toda la ciudad causó admiración'.

10 The debate is reflected in the the data on record in AUS, 113, fol. $68^{\mathrm{r}}$ and referred to diplomatically by Lançina in his Relación (as in n. 8), fols $4^{\mathrm{r}}, 5^{\mathrm{r}}$. 


\section{RELACION.}

DELAFVNERAL POMPA, EN LAS HONRAS que hizo la muy infigne $V$ niuerfidad de Salamanca,er: XXI.deDeciembre de M.DC.XLIIII.años,

Ala buena memoria,y Mageftad dela Reyna N. S.D. ISABEL DE BORBON muger del muy Catholico Monarcha de Elpaña, y Emperador de America l'HILIPO IIII, EL GRANDE N. S,

Siendo Rector don lofeph de Andia Irarrazabal, hermano del Vizconde de S,Clara,

$$
\mathrm{Y}
$$

Maeftrefcuela D.Luys Venegas de Figueroa, del - Confejo de fu Magettad, Obifpo electo de la Ciudad de Almeria,

\section{DEDICALA}

A la Mageftaddel Rey nuestro Señor. HAZELA

Por comifsion de la Vniwerifidad, $t$ Doctor $D$. Luys Felix de Lançina, y Vlloa.

En Salamanca,gor la Imprenta de Francifco de Roales.

Fig. 58-Luis Félix de Lançina y Ulloa, Relación de la funeral de Isabel de Borbón, title page 
all, the possibility of transferring events from the cloister, where such ceremonies had been held since the time of Philip II, to the chapel of San Jerónimo. This would minimise costs and avoid shortening the university term by one month. In the end, the limited capacity of the church swayed the vote in favour of the cloister. The joy of the students at the unexpected holiday was mitigated by the cancellation of the procession that was traditionally held at funeral ceremonies. ${ }^{11}$

But if the decision to hold the university's commemoration in an open area solved difficulties of space, it necessitated the construction of platforms and other temporary structures. The cloister was arranged as if it were a theatre, with a central stage, occupied by the catafalque, surrounded by tiered seating for spectators. A rostrum was constructed for the high altar where mass would be celebrated, together with two pulpits for the reading of the epistle, gospel and funeral oration, and a kind of platform where fortunate spectators could have an unobstructed view of events ('sin embarazo las historias'). A number of temporary galleries were installed in the upper part of the cloister, following the design of those erected in the same positions some years earlier, for the obsequies of Philip III. ${ }^{12}$ In the four corners of the lower galleries of the courtyard, which were adorned with hangings, hieroglyphs and poems, the university colleges, in order of seniority and following a strict etiquette, erected their own catafalques, altars, candles and rostrums for musicians and priests. ${ }^{13}$ Finally, in order to provide shelter against inclement weather, the courtyard was covered by an awning 'in the shape of a pavilion', greatly praised by Lançina for its elegance; indeed the artists who had raised it in the air had shown more skill than the fabulist Aesop. ${ }^{14}$

In the civic celebration the royal cenotaph was the centre of attraction, so the organisers, sparing no effort, chose the best designs submitted and entrusted their decoration to the best talents available. The lack of printed descriptions, however, as well as the sketchy nature of the data given in the records, makes it difficult to arrive at any idea of the design. Still, as it was made by Andrés de Paz ${ }^{15}$ who was also responsible for the university's catafalque, I suspect that it would not have been very different in character from that one. We know little more about the catafalque of the clergy of San Marcos, since their modest leaflet tells us only that the structure consisted of three tiers fashioned with 'pilasters, columns, cornices and shields with the royal coat of arms'. ${ }^{16}$

\begin{abstract}
11 Classes ended on 22 November, a month earlier than normal, so that construction work could begin. The procession, which started in the convent of Santa Ursula and went through the city to the university building, was cancelled so as to avoid disturbances ('las discordias entre ciudadanos y estudiantes... al encontrarse los de una nación con los de otra'); AUS, 113, fols $64^{\mathrm{v}}, 68^{\mathrm{v}}-9^{\mathrm{r}}$, $72^{\mathrm{r}}, 73^{\mathrm{r}}$.

12 Since the ephemeral elements of these upper cloisters were identical to those erected for the obsequies for Philip III in 1621, I omit their description, which can be found in Montaner (as in n. 1), pp. 536-9. The Relación (as in n. 8), fols $9^{\mathrm{v}}-12^{\mathrm{r}}$, gives details of the layout of the cloister in the 17 th century, with the lower galleries ending in 'una cornisa antigua de moderado vuelo...y guarnición de bolas elevadas.'

13 San Bartolomé, the most senior of the colleges, occupied the eastern corner; Santiago el Cebedeo or the College of Cuenca was installed in the south; next came
\end{abstract}

San Salvador de Oviedo in the northern corner; and in the west was the College of the Arzobispo Fonseca.

14 'mostraron en levantarle y prenderle en el aire los artífices más destreza que el fabulador Esopo': Relación (as in n. 8), fol. 12r .

15 The designer Andrés de Paz seems to have specialised in the construction of ephemeral architecture. He never attained the professional standing of his brother, the sculptor Antonio de Paz, who participated in almost all the important works carried out in Salamanca during the first half of the 17th century. For further information see A. Rodríguez, G. de Ceballos and A. Casaseca, 'Antonio y Andrés de Paz y la escultura de la primera mitad del siglo XVII en Salamanca', Boletín del Seminario de Arte y Arqueologia, Valladolid 1979, pp. 413-16. The design for the civic cenotaph, chosen from among three projects, was approved on 31 October 1644 (Salamanca, Archivo Municipal, Libro de Consistorio, no. 28, fol. 441 ${ }^{\mathrm{r}}$ ).

16 Arando y Mazuelo (as in n. 7). 
The account of the university obsequies, on the other hand, although mostly concerned with the symbolic content of the celebration, ${ }^{17}$ gives a detailed description of its catafalque, appropriate to its importance. The majestic pyramid, over twenty metres in height, was essentially the same as that commissioned by the university for the funeral rites of Philip III two decades earlier. ${ }^{18}$ But the dome on top was now replaced by a crown. The structure was put together, using existing elements, by Andrés de Paz (who may also have designed the previous version), with the help of his brother Antonio and the wood carver Miguel García. ${ }^{19}$ The painter Pedro de Tordesillas was instructed to put to best possible use the canvasses and frames owned by the university. ${ }^{20}$ The pyramid was composed of three tiers of decreasing size, on a platform base. The bottom tier had four sides, the middle tier had eight—'so that they could harmonise with the four openings of the arches facing the façades of the catafalque... and the other four would face the four corners of the corridor'-and the top tier had twelve sides-'so that the openings in its arches would correspond, some to those in the first section and others to those in the second'. ${ }^{21}$

Much ingenuity was spent to ensure that the funeral decorations would draw a great crowd and make the event a memorable one. There were splendid ornaments, unusual and striking materials such as black baize cloth from Flanders, shields with the royal coat of arms, groups of singers and musicians, and an abundance of lights. ${ }^{22}$ The academic community had the advantage over the other bodies involved in the Salamanca ceremonies not only in having the cloister of the Escuelas Mayores as a setting, but also in the theological and legal experts and the library resources it could count on for the preparation of the programme.

The university records reveal that the main scholar behind 'the learned and solemn adornment' ('el docto y grave ornato') was the famous jurist Don Francisco Ramos del Manzano, who at the time held the principal chair in law, one of the most prestigious positions in the university. ${ }^{23}$ It might indeed be that his role in this event served to consolidate a rising political career. Already a member of the king's council, at the time of the obsequies he was (or had recently been) appointed president of the Council of Milan. Later he was to become tutor to Charles II, and regent and president of the

\footnotetext{
17 The organisers attached little importance to the formal aspects of the event. See e.g. Relación (as in n. 8), fol. $31^{\mathrm{r}}$ : "Mas aunque se esmeró sumamente en estos adornos el cuidado y destreza de la arquitectura, menos le debieron a la curiosidad de los ingeniosos que la varia erudición y docta variedad de jeroglíficos que los animaban'.

18 I have not found any drawings or engravings of the funeral monuments in Salamanca up to the period under study, but by following the descriptions in the corresponding Relaciones I have attempted reconstructions of the university cenotaphs for Margaret of Austria and Philip III (Montaner, as in n. 1, p. 542 and p. 544, figs 3-4). The similarities in form between these two, and also Isabella's-though partly due to the 'recycling' systematically referred to in the archives-points to a model established at the funerals of Charles $\mathrm{V}$ and Philip II. L. Cervera Vera, 'Túmulos Reales diseñados por Francisco de Mora', Boletin de la Real Academia de Bellas Artes de San Fernando, 1976, p. 32, suggests the existence of a prototype which, with small variations, was repeated throughout the first half of the century.
}

19 AUS, 1329, fol. $45^{\mathrm{r}-\mathrm{v}}$.

${ }^{20}$ AUS, 113, fol. 9 ': 'lo que se pudiere de los cuadros y marcos que tiene la Universidad'.

21 Relación (as in n. 8), fols $36^{\mathrm{v}}, 41^{\mathrm{v}}$.

22 Claude François Menestrier, Des décorations funèbres, Paris 1683, p. 181, writes that 'les lumières en doivent faire la partie la plus considérable'.

${ }^{23}$ For Ramos del Manzano see E. Esperabe de Arteaga in Diccionario ilustrado y crítico de salmantinos ilustres y beneméritos, Madrid 1952, p. 160; A. Riesco Terrero, 'Don Francisco Ramos del Manzano: catedrático salmantino y destacado político de nuestro siglo XVII', Salamanca y su proyección en el mundo (as in n. 1), pp. 246-58. According to the record of the university senate meetings, AUS 113 , fol. $6^{\mathrm{r}-\mathrm{v}}$, in supervising the scholarly decorations for the obsequies for Isabella of Bourbon, Ramos del Manzano had the help of Fray Antonio de Ledesma, Fray Francisco de Aragón, Father Pedro Merino, Dr Hontiveros and Maestro Reyes. See also Appendix Ia. 
Supreme Council of Castile. It is also probable that Ramos del Manzano had poetic talent, as can be guessed from an excellent sonnet that Lançina attributes to him, albeit obliquely (Appendix Ib).

Lançina's account of the programme is supported by many marginal citations which not only testify to the literary concerns of the designer, but to the humanist character of his library. Unusually for a programme of this kind, which would normally have been planned by a cleric, the majority of references are to classical literature-often known through convenient handbooks and anthologies-and especially to those authors who, in recalling the greatness of the Roman past, sought to evoke the glories of the empire..$^{24}$ Although he had to treat the basic, funereal themes, it seems that Ramos had complete freedom in the material employed to contruct his narrative-and this accounts for the specific character of the programme. This freedom was partly a result of the academic setting: systematic reference to the wisdom of the ancients, or extensive use of mythological metaphor, would not have been suitable in a sacred space.

The author contrived a symbolic mode of discourse in which Ovid's Metamorphoses and the treatises commonly drawn on by emblematists-the works of Horapollo, and Cartari; and Valeriano's indispensable dictionary, the Hieroglyphica-played a part; equally significant, however, were the Diálogos de medallas, inscripciones y otras antiguedades of the polymath Antonio Agustín, one of the most outstanding of Spanish humanists. ${ }^{25}$ We find reference to Plautus and Terence, Plutarch or Propertius, as well as to Aristotle, Cicero and Seneca, the philosophers dearest to Christian humanism. Also included are witty epigrams by Martial, an ancient Spaniard. These were taken, as can be deduced from the Relaciones, from the edition published by Petrus Scriverius in Leiden in 1618-19, which incorporated annotations and commentary of Poliziano and Giovanni Pontano. The satirist Sulpicia, supposed author of maxims written during the tyranny of Domitian, appears too; ${ }^{26}$ in fact, from a linguistic point of view, the hexameters attributed to her have more the character of works from late antiquity or even the Middle Ages. Undoubtedly, however, Vergil, 'Prince of Poets' was the principal source of images and metaphors.

Historical data was supported by among others, Polybius, the agricultural treatise of Varro, the histories of Suetonius, Silius Italicus, Tacitus and Appian as well as a work attributed to Sempronius Tuditanus. ${ }^{27}$ Not surprisingly the compendious Lives of the Philosophers by Diogenes Laertius was found useful. Information relating to astrology, one of the more prestigious sciences taught in the classrooms of Salamanca, derives from Manilius's Astronomica, while the animal and other metaphors were mainly derived from the well-known works by Pliny and Aulus Gellius. Among other ancient sources used by the author of the programme, either directly or through compilations, were the Neoplatonist Macrobius and the Christian writers Tertullian, Claudian, Prudentius and Sidonius Apollinaris.

There are also references to modern authors; Ramos del Manzano was evidently familiar with the Adages of Erasmus, and Spanish works, some of them linked to the studium in Salamanca-Juan de Mena, Sebastián de Covarrubias y Orozco (whose

\footnotetext{
24 This becomes evident when the university text is compared with the books of accounts written by other institutions. See e.g. Pompa Funeral. Honras y Exequias en la muerte de la muy Alta... Señora Da Isabel de Borbón... que se celebraron en el real convento de San Jerónimo de Madrid..., Madrid 1645, studied by S. Orso, 'Praising the Queen: The Decorations at the Royal Exequies for Isabella of Bourbon', Art Bulletin, lxxii, 1990, pp. 51-74.
}

25 See Antonio Agustín: Between Renaissance and CounterReform, ed. M. H. Crawford (Warburg Institute Surveys and Texts, xxiv), London 1993.

26 This Sulpicia has nothing to do with the poetess of the same name who lived in the time of Augustus.

27 See below, n. 29. 
Treasury of the Castilian Language was published thirty years before the programme was drawn up) and the great Góngora, whose presence was still felt on the banks of the Tormes.

It is tempting to think that much in the funerary tributes-many in Latin and a few in Greek - was aimed at displaying the author's command of poetic technique, and facility in the use of classical metre: asclepiads, phalaeceans, hexameters and distychs. Certain gods and personifications that were particularly in vogue in humanist circles duly make an appearance. Hermathena, for example, that hybrid figure who combined the eloquence of Mercury and the wisdom of Minerva, and had once been sought out by Cicero as an ornament for his study, is hardly unexpected in this academic context. ${ }^{28}$ Another ancient reference, apt enough, if unusually erudite in a funeral programme, was to the goddess Angerona who, conflated with Harpocrates, illustrated the 'grief and silence' that the death of Isabella caused in her subjects. ${ }^{29}$

In his survey of funeral festivals, Claude François Menestrier writes that the central theme (the 'soul') of exequies should express the vanity of human grandeur, the eternity of the soul and the glory of Christian virtues. ${ }^{30}$ In connection with the rites associated with Spanish royalty, these notions can be seen as ideological tools in the service of power. The very figure of the deceased makes an argument in favour of the crown as an institution; the immortality of the soul provides an expression of the permanence of the system; and the declaration of the virtues of the deceased constitutes a description of the ideal Christian ruler.

We might suppose that, since the university programme broadly respected tradition and convention, the content might have been a mere reworking of commonplaces and stereotypes. But the series of emblems and allegories that the university presented to its optima parens et regina-although subject to the established rules and precedents that had been elaborated on the basis of previous accounts of obsequies and of the last illnesses of sovereigns-differs from those accorded to monarchs earlier in the century. The exequies for Margaret of Austria, in 1611, represented a conventional pattern of a queen mother, as a perfect example of a Christian wife and mother. Those for Philip III, in 1621, although comparable in their degree of erudition, amounted to a conventional exaltation of the dynasty and a defence of monarchy as the best form of government. ${ }^{31}$

Since the event was to be a propagandistic display in the service of authority, the programme was directed above all at counteracting the symptoms of decadence

28 E. Wind, Pagan Mysteries in the Renaissance, Harmondsworth 1967, p. 203, points out the intellectual nature of these mythological combinations that the authors of the programme in Salamanca may have taken from Vincenzo Cartari, Le imagini de $i$ dei de gli antichi..., Venice 1571, p. 356. There are images of Hermathena in the emblem of the academy of Achille Bocchi and in the decoration of the studiolo of the Farnese Palace of Caprarola, commenced in 1566 by Federico Zuccaro. See E. McGrath, 'Rubens's Musathena', this Journal, 1, 1987, pp. 233-45 (240-1) and pls 68a, 69a; C. Robertson, Il gran cardinale Alessandro Farnese, New Haven, Conn. and London 1992, p. 109 , fig. 96.

${ }^{29}$ Angerona is overburdened with attributes: she is described as crowned with cypress, with her throat and mouth bound up, her right index finger sealing her lips, and her left hand holding a peach. Except for the cypress (the plant of death), this conflation of Angerona and Harpocrates seems directly inspired by Cartari (as in n. 28, pp. 374-6). Strangely enough, Cartari is not quoted by Lançina, who refers (in this order) to Pliny, Solinus (Polyhistor), Sempronius (De divisione et chorographia Italiae), Macrobius (Saturnalia), Varro (De lingua latina), Statius, Ovid, Plutarch (Isis et Osiris). The list is closed by two truly relevant sources to the Relacion: Antonio Agustín, Diálogos de medallas, inscripciones y otras antiguedades, Tarragona 1587, Diálogo V, p. 194; and Pierio Valeriano, Hieroglyphica, Basle 1575, liv, fol. $397^{\mathrm{r}}$.

30 Menestrier (as in n. 22), pp. 5, 62, 65 .

31 On the existence of two funeral patterns, one for a king and one for a queen, see Montaner (as in n. 1), p. 546. 
besetting the dynasty and at instilling hope into discontented subjects burdened by taxes. With the Habsburgs facing threats of rebellion at home and catastrophe abroad, the author chose to improve on the reality of the present by reference to ancient magnificence; he compared the mission of Spain in the world to the Roman path to imperial grandeur, making use of the legendary, mythological and historical material. ${ }^{32}$ His aim seems to have been to vindicate, on the one hand, the firmness of purpose that Isabella had shown during her brief regency, in the absence of her husband in Catalonia, and, on the other hand, her effective participation in the rehabilitation of monarchical authority, after it had been eroded by the unpopular Count-Duke of Olivares-in whose dismissal Isabella was thought to have played a crucial role.

Given the hostile relations between France and Spain, aggravated by the disaster of Rocroy in 1643, it seemed important to strengthen the connection with the Habsburg court of Vienna, so as to curb French attacks on Spanish hegemony in Europe (finally lost at Westphalia in 1648).$^{33}$ This policy of friendship and collaboration was highlighted in the university's programme in hieroglyphs and allegories prominently displayed on the catafalque. To this end, 'erudición gentil cristianada' ('Christianised pagan learning') —as Lançina elegantly put it—presented the sovereign as mother, protector and benefactress of the realm, extolling her 'varoniles hechos' ('manly deeds': the epithet implies both bravery and valour), and her political qualities: prudence, dedication and skill in governance. All this together with her representation alongside her husband, whose inclusion in the programme, to judge by the defensive tone of the Relaciones, gave rise to criticism in some sectors as unsuitable (Appendix Ic).

In her role as royal consort, Isabella was hailed as Juno, Bellona, Minerva in the role of agent of Jupiter, or as Iris, herald and messenger of the gods. Philip IV was acclaimed as the Spanish Caesar, and likened to the fourth planet (Mars), Apollo and Jupiter.

Isabella's spiritual qualities were summed up in the image of the lily. This was appropriate enough since, apart from the French associations of the fleur de lis, the lily is the emblem of Juno; it was employed by the Romans as a symbol of hope in the fortunes of the Republic; and the species is conflated in classical sources with the iris, which represents the Olympian messenger with whom the queen was compared. The whiteness of the lily indicated purity; the fertility attributed to the root of the iris'and nothing is more fertile' (nihilque est fecundius) - alluded to the importance of her role in the royal succession; and the connection of the iris (so named because of the variety of colours in its petals) to the rainbow, arcus iridis, characterised her serenity and pacific nature.

One of the techniques used in mass spectacles consists in involving the public: instead of passively attending, they somehow take part in the action. Accordingly an attempt was made to elicit responses indicative of gratitude and devotion to the established order from those present - or from later readers of the Relacion. Rhetorical aids were invoked: for example, inscriptions or epitaphs that had been formulated in the second person singular appealed directly to the individual spectator, ${ }^{34}$ or

32 On comparing the glories of the Austrias to those
of the Roman empire, Ramos del Manzano is simply in
line with the political thought in the age of Philip II; see
J. H. Elliott, El conde-duque de Olivares, Barcelona 1990,
p. 70 .
33 For this collaboration, based on the similar interests of the two branches of the House of Austria, see Elliott, op. cit., pp. 370, 394, 451.

34 For example, a funeral eulogy inscribed on the platform of the catafalque (Relación, as in n. 8, fol. $20^{\mathrm{r}}$ ): 'Viator da lilio lilia, et disce mortem praevertere messe virtutum, ut immortalem habeas mercedem gloriae.' 
presented what would now be called a subliminal message that the death of a sovereign is a kind of voluntary offering for the good of the people. ${ }^{35}$

The hagiographic eulogies published to commemorate the queen claim that three drops of blood appeared on her lips at the moment of death. ${ }^{36}$ The symbolic potential of this was irresistible, inspiring lofty commentaries, some presented as ingenious entertainments. An example was the group of compositions which accompanied one of the hieroglyphs submitted to the competition by Don Luis Venegas de Figueroa, maestrescuela of the university. This hieroglyph showed the arm of death with three red military insignia, supposedly inspired to strength by their bloody colours ('con el valor ... de la sangre que los baña'), vanquishing three herds of animals, the rebels of Flanders, Catalonia and Portugal. It had a Castilian quatrain. ${ }^{37}$ The accompanying compositions were laid out as labyrinths, in the fashion of the figured poetry of the Baroque, in which verses can be read in both directions and form a geometric shape: a square composed of smaller squares each of which carries a letter of a phrase or sentence-the extent of the whole being determined by the length of the sentence which forms the lateral boundaries. ${ }^{38}$ The maxim Robur agas animo e de omina saga rubor inspires the first cubic labyrinth (Fig. 59). The consonant ' $R$ ', at the beginning and at the end, printed in red, marks the diagonal of the square formed from the thirty-one by thirty-one small squares. The vowel ' $\mathrm{A}$ ', again printed in red, is the first and last letter of the next palindrome, Asi le baña Belisa, the first line of the Castilian quatrain; it marks the diagonal of a square of fifteen by fifteen small squares (Fig. 60).

Death itself, suggested in many forms, appears as the underlying theme. In the catafalque that the university constructed for Isabella, the few macabre references seem intended to inspire serenity and hope, much needed in an age of crisis. Assurances of a prosperous and happy future replaced the usual lesson of disillusionment, and the queen's soul, secure and eternal, triumphed over the bitterness and grief of death. Whether all this was understood by the crowds is another question. In Baroque celebrations the desire to emulate and surpass previous and rival ceremonies called for the exercise of wit and invention in devising enigmas and metaphors, yet for the ideological content to have any broad influence it needed to be presented in a reasonably accessible manner. After all, the message would have lost its effectiveness if it had only been understood by a learned minority. Given that the painted stories were of contemporary events and that the biblical or mythological scenes were to some extent familiar in the culture of the period, it might be reasonable to conclude that quite a proportion of the spectators grasped something of the content. Despite the difficulty that the emblems present, they were aimed, like the drama, at social

35 See e.g. Relación, fol. $18^{\mathrm{r}}$, 'Pagaba [la Universidad]
en sacrificios y alabanzas las deudas en que estaban a
los desvelos y fatigas que por el bien de cada uno y
sosiego de todos padeció gustosa'; fol. $32^{\mathrm{v}}$, 'Hizo del
erial de este siglo prado y pasto agradable de socorro a
las necesidades mayores de sus vasallos'. Similar concepts
are present in the funeral sermon of Father Pimentel,
e.g. fol. $52^{\mathrm{v}}$, 'Con qué pagaremos Señora ... las asisten-
cias para dar victorias a los ejércitos, vida a sus reinos';
or fol. $53^{\mathrm{r}-\mathrm{v}}$, 'todo el vivir quiso su grande celo para el
trabajo de los despachos, para la fatiga de las asistencias
$\ldots$ midiendo el amor a sus vasallos con el de Cristo...
para redimir al mundo vive Cristo ... vertiendo su sangre
muere [la reina] por redimir a sus vasallos'.
36 Printed accounts reflecting the last moments of
monarchs were disseminated extremely quickly. Two
examples are J. Micheli y Marquez, El cristal más puro representando imágines de divina y humana política para ejemplo de príncipes, labrado de las acciones heroicas de Da Isabel de Borbón..., Saragossa 1644; and Iournal de tout ce qui s'est fait et passé à la mort de très haute et très puissante Izabel de Bourbon, Reyne d'Espagne, Paris 1644 (in Varela, as in n. 1, p. 207).

37 'Así le baña Belisa / a su albo lilio en carmin / que mil bestias en su fin / huirán su roja divisa.' A Latin verse, inspired by Jeremiah 4.7, 'rubicundiores ebore antiquo sapphiro pulchriores', formed part of the hieroglyph. Relación (as in n. 8), fols $79^{\mathrm{v}}-80^{\mathrm{r}}$.

38 Many studies have been dedicated to this genre, known by theorists as figural poetics. See the introduction by V. Infantes de Miguel to Juan Caramuel, Laberintos (Rome 1662), facs. edn Madrid 1981; and F. Rodríguez de la Flor, Lecturas de la imagen simbólica, Madrid 1995, pp. 209-32. 


\section{IN TRES GVTTAS SANGVINIS, QVAE}

APPARVERVNT IN ORE ELISABETHAE BORBONIAE HISPANIARVM REGINAE TEMPORE OBITVS

CARMEN RETROGRADVM.

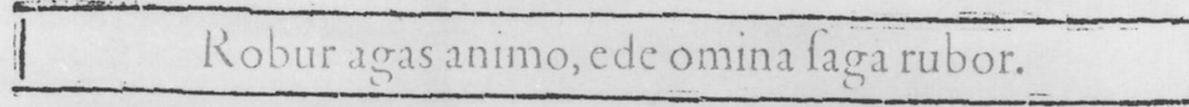

Carminis inverft numeris bis pandit Elta Hifpanis moriens, que omina fausfa dedit. 'Sanguinisora tribus maduerunt Regia guttis, Et fausti aufpicÿ ( f c capis ) omen habent.

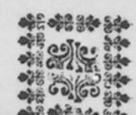

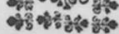

Sacra redimitas ornabat purpura obantes Gloria erat palme, roboris almus bonos:

Ergo firectè, capias hic figna rwboris, In palmas cedent omina tanta tibi.



๑) Sià quaque incipias rubra Rho (Lector amice)

- Qua placeat pergas, carmen vbique fluet.

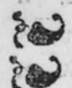

Fig. 59-Robur agas animo e de omina saga rubor, labyrinth proposed by Don Luis Venegas de Figueroa. From Lançina y Ulloa, Relación de la funeral de Isabel de Borbón 


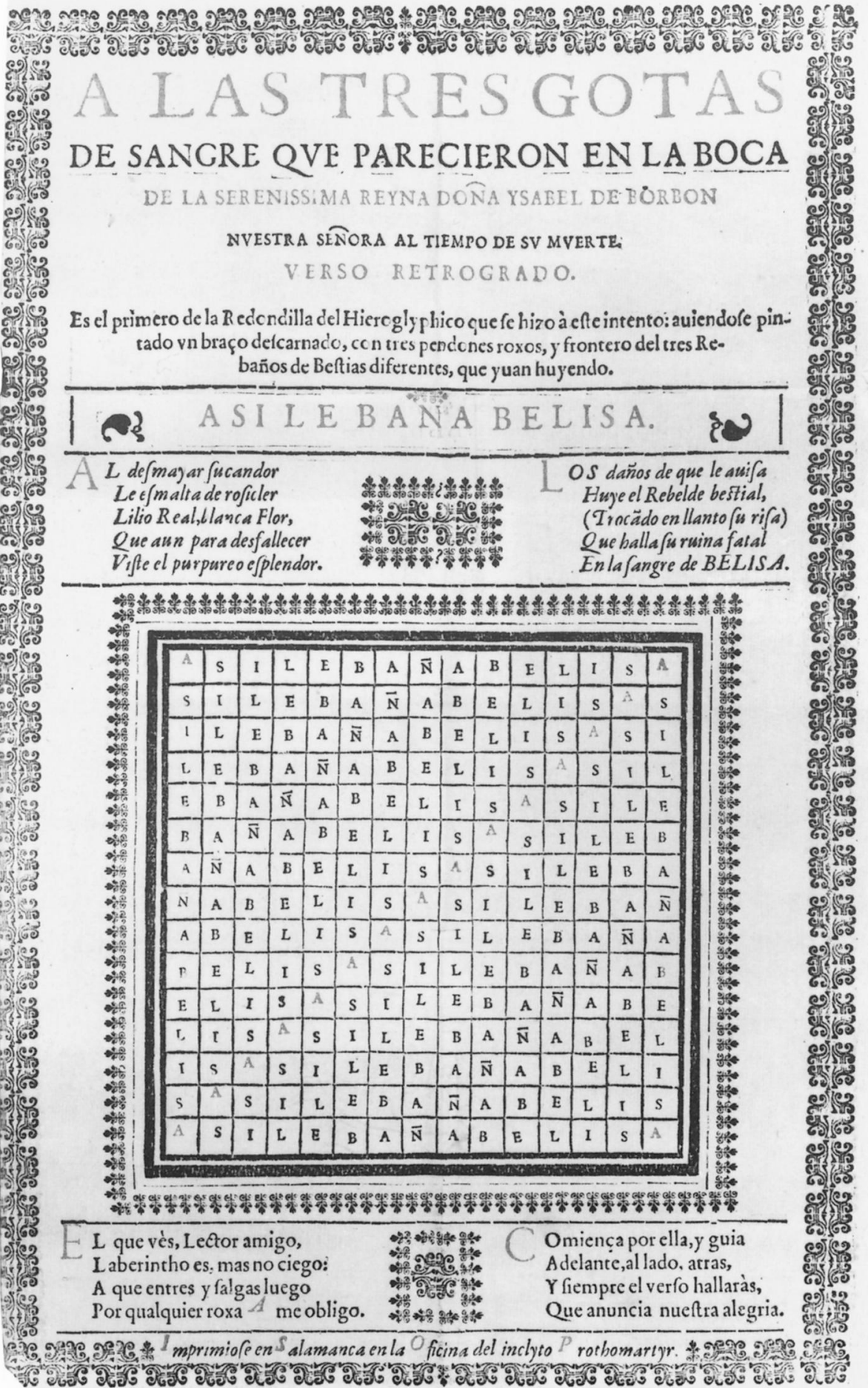

Fig. 60-Asi le baña Belisa, palindrome proposed by Don Luis Venegas de Figueroa. From Lançina y Ulloa, Relación de la funeral de Isabel de Borbón 

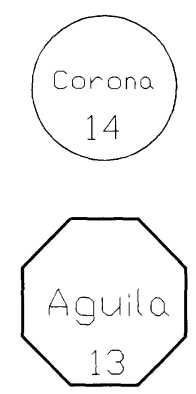

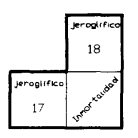

9



10

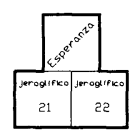

11
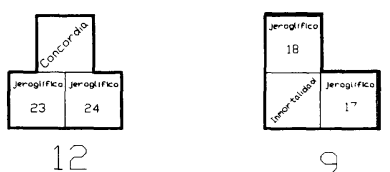

9

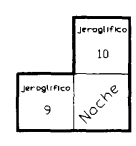

5

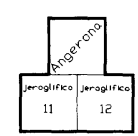

6

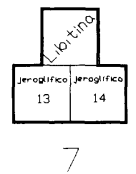

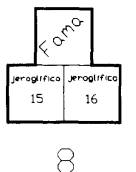

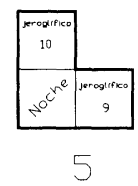

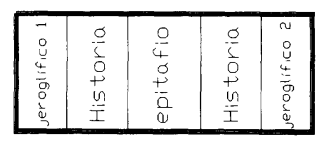

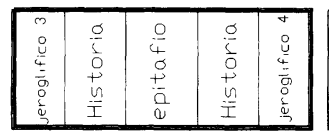

$\curvearrowright$
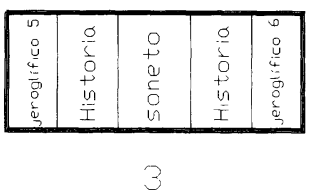

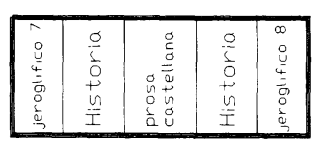

4

Fig. 61-Ground plan of the cloister of the University of Salamanca, showing the positions of the symbolic elements at the exequies for Isabella of Bourbon, December 1644

objectives. ${ }^{39}$ However, the elaborate epitaphs, the sophisticated Latin and even in a couple of cases Greek verses, as well as the iconographic subtleties of the paintings, would have escaped all but the intellectual elite of the university .

Once the basic ideological content had been outlined, the next step in the elaboration of the programme was to contruct a coherent argument using metaphor and allegory. Here originality in the overall content was more important than in the details of the imagery; subjects and iconographic motifs were taken from the standard handbooks and repertories. Even in this funereal context Ramos del Manzano referred more readily to ancient myth and legend than to sacred texts in choosing gods and heroes to exalt the deeds and political projects of the House of Austria.

Since the Relación tried to compensate for the lack of illustrations with a dense and complicated description full of rhetorical figures, I have provided two simple diagrams to illustrate the scheme (Figs 61-2) while the appendices transcribe what seem to me to be the most significant parts of the text.

The image of Hermathena, made of Minerva and Mercury with hands joined, facing the entrance to the cloister (puerta principal, Fig. 62, no. 1), can be regarded as 
ISABELLA OF BOURBON

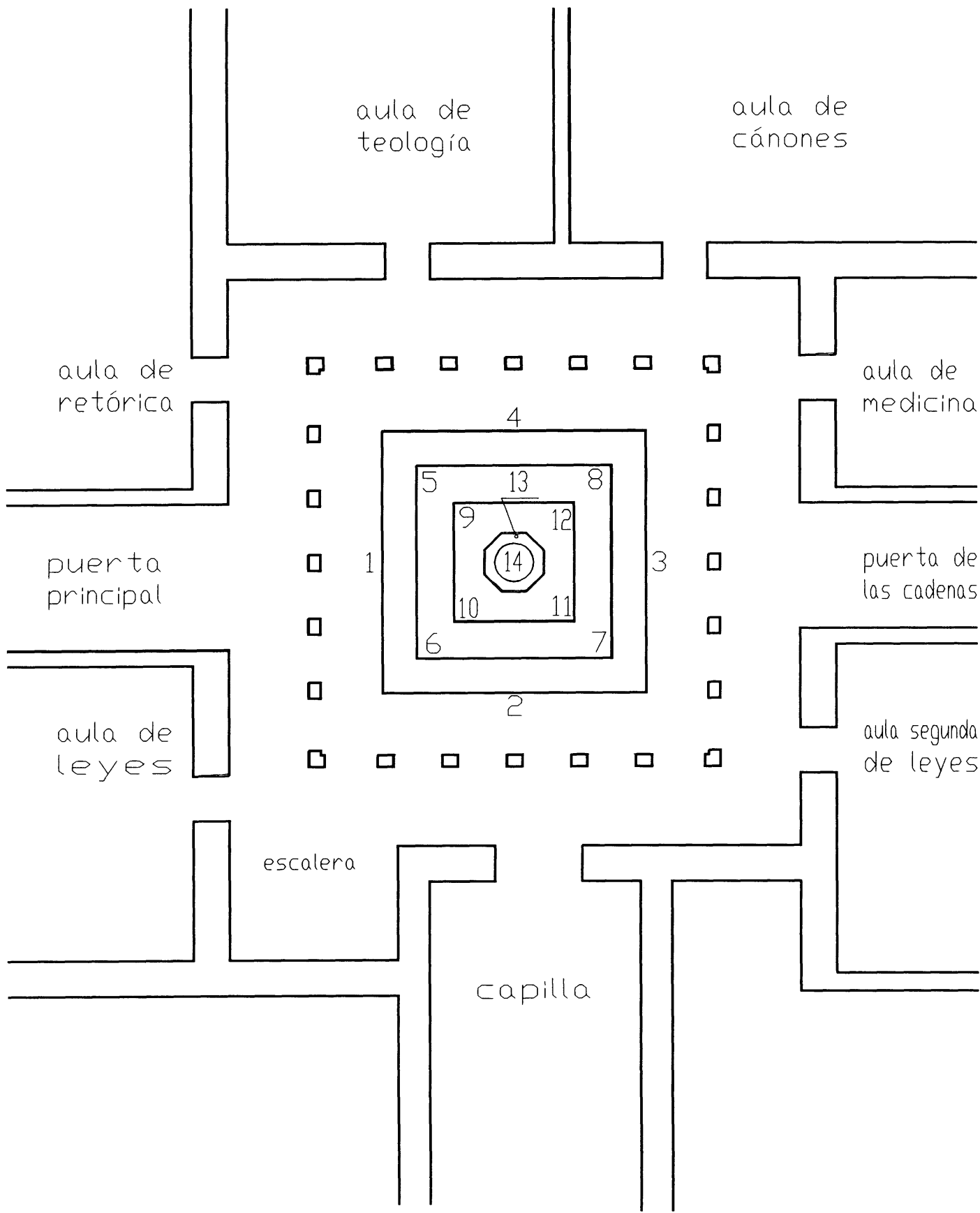

Fig. 62-Diagram indicating the positions of the symbolic elements on the University of Salamanca's catafalque for Isabella of Bourbon, December 1644

the prelude to the programme, summed up by the mottoes taken from Sulpicia, 'virtus belli' and 'sapientia pacis' over the head of the two gods. ${ }^{40}$ Isabella's glorious

40 Sulpicia, Satyra de statu Republicae et temporibus Domitiani, in Ausonius, Opera, Bordeaux 1580, v. 23: 'Roma

caput, virtus Belli et sapientia pacis'. 
deeds were narrated in eight scenes, each with an attached enigma; these flanked eulogistic inscriptions on simulated marble plaques on each of the four faces of the base of the pyramid (Fig. 61, nos 1-4, historias). The whole was designed to be read anticlockwise, and beginning from the Hall of Rhetoric (Fig. 62, no. 1) with a representation of the first link in the chain of benefits brought to the nation by the queen. This was the double matrimonial bond-of Anne of Austria, daughter of Philip III of Spain, to Louis XIII; and of Isabella of Bourbon, daughter of Henry IV of France, to Philip IV-arranged in 1615 by the French Regent Maria de' Medici to consolidate peace between Spain and France. The scene was allegorised in a hieroglyph adapted from the well-known enigma that Samson posed to the young Philistines: a crowned lion, alluding to the arms of Castile, from the jaws of which sprang a lily, symbol of the House of Bourbon. A swarm of bees gathered their sweetness from the lily, in an image intended to suggest how the Franco-Spanish alliance, with its fruits of peace, benefited the vassals of both crowns (Appendix IIa, Hieroglyph 1).

To vindicate the union and illustrate the happy consequences-as Lançina shrewdly observes-on the same side of the podium, opposite the Hall of Law (aula de leyes), was the defeat of the Huguenots at La Rochelle, attributed to the intervention of the Spanish under the command of Don Fadrique de Toledo. (In fact, the Spanish fleet would have preferred to oppose Louis XIII's troops had it not meant supporting heretics.) The hieroglyph compared the surrender of the city, 'receptacle of heretics', to the destruction of Troy and of the unfaithful king Laomedon, punished by Apollo (Philip IV), Neptune (Don Fadrique de Toledo) and Hercules (Louis XIII) (Appendix IIa, Hieroglyph 2).

On the adjacent side of the platform, between the staircase of the cloister and the second Hall of Law (Fig. 62, no. 2), were two scenes: one showed the late queen accompanied by Prince Baltasar Carlos, heir to the throne, reviewing the troops which, financed by her resources, were to be sent to defend the frontiers of Catalonia and Extremadura; the other showed her as ruler, seated on a dais under a canopy and conversing with ministers. The accompanying emblems featured an eagle with a shaft of lightning between its talons, testing its eaglet by presenting it to the sun-only true born eagles could supposedly look directly into its light ${ }^{41}$ —and Jupiter waiting to receive the thunderbolts borne by two young eagles, were intended to signify, respectively, the legitimacy of the heir to the throne, and the dispatch of troops to deal with the disturbances (Appendix IIa, Hieroglyph 3).

The image of the rainbow, sign of God's covenant with mankind (Genesis 9.13), was related to Iris of ancient myth, depicted as a maiden crowned with the iris lilies which, symbolising eloquence, illustrated Isabella's powers of persuasion, in an image of the conciliatory role played by the queen during her regency (Appendix IIa, Hieroglyph 4).

Of course reference had to be made to the organisers of the whole display; this appeared on a canvas set up on the side of the podium corresponding to the so-called door of the chains (puerta de las cadenas) and showed students and professors of the university overwhelming Portuguese rebels on the frontier at El Gardón, near Ciudad Rodrigo (Fig. 62, no. 3). The corresponding impresa proclaimed the university's loyalty with an image of Minerva, goddess of military courage and of learning, conquering the giant Pallas who had sought to dethrone Zeus, not by arms but by the fear that her visage inspired (Appendix IIa, Hieroglyph 5).

41 See below, n. 65 . 
The programme continued, in triumphalist tone, with accounts of victories on the battlefield, presented as just punishments for the insolence of those who opposed the spiritual and civil supremacy of the Spanish monarchy. Illustrated on the part of the pedestal corresponding to the Hall of Medicine, these involved the recapture of the castle of Monzón; the retaking of the city of Lerida in Huesca, defended by the Count de La Motte, then viceroy of Catalonia; and the capture of Montijo in Portugal. The political results of these victories were ambiguous and contradictory, but they were presented in the programme as examples of the power of the House of Austria. The emblematic images highlighted the message by showing a palm tree representing Queen Isabella, leaning towards Apollo's laurel which stood for Philip IV. From the branches of the palm hung four golden crowns, symbolising victory, and from the laurel tree a corona civica, the award for bravery in the field, an image of the effective collaboration of the late queen in the actions of the troops (Appendix IIa, Hieroglyph 6).

On the adjacent side of the platform, opposite the Hall of Canons (Fig. 62, no. 4), the depth of Isabella's faith was illustrated in a painting showing her attending the octave held every Thursday in the palace chapel, on her knees before the Virgin of Atocha, to whom the Habsburgs were particulary devoted. An emblem inspired by passages from Exodus and the Book of Judges showed a shining column within a cloud dropping dew onto a shell held by a hand and a fleece, to show how the queen received Grod's help with the Virgin as mediatrix (Appendix IIa, Hieroglyph 7).

Two military successes which occurred a few months before the death of the queen -the surrender of Balaguer and the liberation of Tarragona-were represented on the canvas opposite the Hall of Theology; this gave the finishing touch to the catalogue of Isabella's heroic deeds. The significance of the scene was underlined in the emblem Juno liliaca, Venus rosea (Appendix IIa, Hieroglyph 8), which linked the lilies whitened by the milk from Juno's breast to the roses reddened by blood from Venus's feet, thereby alluding to the state of happiness left to her adopted country by the queen, the drops of blood on her lips, and the tears shed by the people upon her death.

Eight hieroglyphs on the pedestals of the columns supporting the next section of the construction further celebrated, mostly in symbolic floral themes, the 'life, virtues and achievements' of the pious daughter of Henry IV (Fig. 61, nos 5-8). Motifs of heraldic origin, such as the eagle above a castle with a fleur de lis in its beak, alluded to the Habsburg-Bourbon marriage (Appendix IIb, Hieroglyph 9). Isabella's chastity was linked to the archetypal lily growing among thorns (Hieroglyph 10). The crowned heart on the calyx of a lily expressed the protection and support that the queen gave to her husband (Hieroglyph 11). A fleurdelisée sword and a sceptre crowned with a lily referred to the strength and wisdom she showed during her regency (Hieroglyph 12). A familiar example of trusting to providence, the lilies of the field protected by heaven, paid tribute to her faith in divine mercy (Hieroglyph 13), and her beneficent care for the people was evoked by the image of a flock of sheep grazing in a pleasant meadow of lilies (Hieroglyph 14). The three drops of blood seen on her dying lips were symbolised by a lily and three red roses in a glass vase (Hieroglyph 15). Finally, a withered palm tree, crowned by a flourishing fleur de lis which proclaimed the immortality of the queen's soul, stretched its branches eastward towards Catalonia and to Philip IV, expressing the strength of her conjugal love even after death (Hieroglyph 16).

The universal mourning conventionally presented in funeral ceremonies through images of the weeping Continents, Seasons or Cardinal Virtues, or the four realms of 
the monarchy (i.e., the most significant possessions of the kingdom),${ }^{42}$ were replaced in the university's scheme by lamentations of the different branches of knowledge taught there. The four major faculties, in mourning and dressed in in black but with caps and capes of their respective colours ${ }^{43}$ supported the tomb and paid homage to their 'mother' and benefactress: Theology with the thurible, Canon Law with the scales of justice, Jurisprudence with justice's sword; while the tears of Medicine bore witness to the grief of the profession that doctors had been unable to prevent the queen's death.

There is no doubt that the professors of the studium of Salamanca made use of theatrical devices in their programme. ${ }^{44}$ Spectators were confronted with a silent conversation conducted by four pairs of allegorical figures, situated on the first and second sections of the catafalque and dressed in real costumes like actresses in the theatre ${ }^{45}$ Instead of following the prescriptions of Ripa, perhaps because the Iconologia was thought to be too obvious a source, Ramos del Manzano consulted Cartari's treatise on mythology, Valeriano's Hieroglyphica and especially the Diálogos de medallas, inscripciones y otras antiguedades of Antonio Agustín, follower of Alciati and a former student at the studium of Salamanca. Having a good knowledge of the classics, he himself added material from Pliny, Vergil, Plutarch and Macrobius. Night, dressed in black - situated on one of the corners of the first storey of the structure (Fig. 62, no. 5) and dark-winged, in accordance with Vergil's description ${ }^{46}$-initiated the dialogue by speaking of the darkness into which the country had been plunged by the death of its sovereign. Angerona (Fig. 62, no. 6) spoke of the silence accompanying affliction, and Libitina (Fig. 62, no. 7), with a scythe in one hand and the funeral ointments in the other, represented the goddess responsible for the care of the dead. Fame (Fig. 62 , no. 8) replied to all three, proclaiming with her trumpet 'the eternal life and happiness' of the queen's soul, thus transforming grief into serenity and anguish into hope. ${ }^{47}$

This encouraging message was directed towards the other four allegorical figures, placed on the corners of the upper tier of the pyramid and accompanied by enigmas; these corresponded each to a member of the royal family (Fig. 62, nos 9-12). Immortality, for Isabella, had a moon and a phoenix - signs of renewal-and a scythe

42 At the time of the funeral of Margaret of Austria in Salamanca, the four realms were Austria, Aragon, Castile and Burgundy (Montaner, as in n. 1, p. 547). For Micheli, at the death of Isabella of Bourbon, the weeping realms were Spain, Italy, Flanders and the Indies (as in $\mathrm{n}$. 36, fols $7^{\mathrm{v}-8^{\mathrm{r}}}$ ). In general, figures suited to the quaternary nature of catafalques became funerary stereotypes. The four parts of the world, the four seasons and the four cardinal virtues appear, for example, on the cenotaphs of the University of Valladolid (Antonio Vázquez de Velasco, Exequias funerales que celebró la muy insigne y real Universidad de Valladolid..., Valladolid 1645, fols $8^{r}-9^{v}$ ), in the convent of San Jerónimo in Madrid (see Orso, as in n. 24, p. 60), and in the cathedral of Seville.

43 The colours belonging to the faculties (some of which are still in use) are white for Theology, green for Canon Law, red for Civil Law or Jurisprudence and yellow for Medicine.

44 J. M. Díez Borque, 'Relaciones de teatro y fiesta en el barroco español', Teatro y fiesta en el Barroco, ed. idem, Madrid 1986, discusses the so-called 'meeting points' between drama and celebration (pp. 18, 36). E. Orozco,
'Sobre la teatralización del templo y la función religiosa en el barroco: el predicador y el comediante', Introducción al barroco, i, ed. J. Lara Garrido, Granada 1988 , p. 269, points out the 'dramatisation of all the arts and life' in the Baroque era.

45 AUS, 1329, fol. $45^{\mathrm{r}}$. The sum of 190 reales was paid to the "clothiers who dressed the figures of the catafalque'.

46 Vergil, Aeneid, viii.369. The design follows Cartari (quoted by Lançina) with small variations (as in $\mathrm{n} .28$, p. 330).

${ }_{47}$ Libitina is presented dressed in black, with a crown of myrtle, carrying a scythe and funeral unction. As for Angerona (for whom see above, n. 29), Lançina quotes multiple sources. Cartari (as in n. 28, p. 303) is again absent, but in my opinion, Ramos may well have taken the Imagini as a basis. Winged Fame is borrowed directly from p. 396 in Cartari. Her green robes, wings of the same colour and crown of evergreen ivy symbolise the eternity of the poet's name. For the horn, the designer(s) must have consulted Valeriano (as in n. 29), xlvii, fol. $349^{r}$. 
to proclaim her triumph over time and death..$^{48}$ Two painted hieroglyphs reiterated the concept (Fig. 61, no. 9). The first emphasised the continuity of her lineage with two fleurs de lis, one descending from above, for the beginning of the dynasty in the time of Clovis, and another rising from the earth, representing the soul of the queen (Appendix IIc, Hieroglyph 17). The heliotrope depicted in the next hieroglyph, in a play on the two meanings of the word-as a sun-worshipping plant and as a type of green agate striped with red-at once reflected Isabella's soul rejoicing in the light of grace, and, through the red stripes, her redeeming blood, in allusion to the three drops that appeared on her lips as she expired (Appendix IIc, Hieroglyph 18).

Constancy, identified with strength, was represented astride two anchors to affirm that the king's strength of mind came from the stability that the guarantee of his issue gave to the realm. Grief at the loss of the queen, tempered only by the eternity of her soul, was symbolised by a crowned head with a weeping face and a diadem of beautiful lilies rising to the sky. A rod of lilies together with a staff ending in a fleur de lis expressed once more the security of the succession, guaranteed by the two offspring (Appendix IIc, Hieroglyphs 19 and 20; Fig. 61, no. 10). ${ }^{49}$

Hope, with a happy face, was the virtue attributed to the Infante Baltasar Carlos; dressed in green and crowned with olive leaves, she raised the hem of her tunic with one hand and in the other held two lilies, an ancient Roman sign of hope in the well-being of the republic. This image was acknowledged to have been inspired by the reverses of coins of Claudius, Hadrian and Alexander Severus, reproduced by Agustín (Fig. 63)..$^{50}$ The hieroglyphs supported the idea that the country's hope lay in the capacities of the heir to the throne, using military emblems and the Order of the Golden Fleece (toisón de oro), insignia of the monarchs of Spain (Appendix IIc, Hieroglyphs 21 and 22;
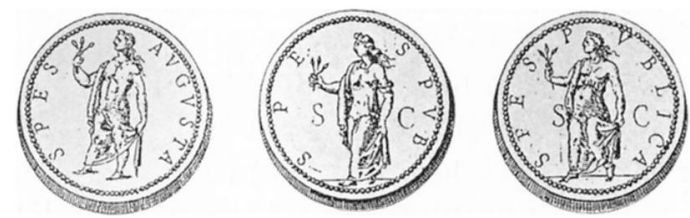

Fig. 63-Coins of Claudius, Hadrian and Alexander Severus (reverses), from Agustín, Diálogos de medallas, Tarragona 1587 Fig. 61, no. 11).

Concord, dedicated to María Teresa (referred to in the Relación as the Infanta Maria), predicted, with the help of a cornucopia and a cartouche with two hands holding a caduceus, ${ }^{51}$ the benefits that would result from 'the continuation of the concord and happy union promised to Spain and Austria through the serenisima

48 To avoid the use of familiar image of the serpent biting its tail from Claudian, the moon was chosen as a symbol of renewal (Valeriano, as in n. 29, xliv, fol. 328 ${ }^{\mathrm{r}}$ ). The phoenix reborn from its ashes is an emblematic prototype used by scholars of all ages. Lançina cites Roman coins, and we find examples showing Aeternitas with sun and moon in either hand, or again holding a phoenix on a globe, illustrated by Agustín (as in n. 29), Diálogo II, p. 41.

49 Again, we are faced with a very personal version of an allegory: Constancy is described by mixing diverse sources. From Agustín (as in n. 29), Diálogo II, p. 52, where she appears as the companion of strength, she takes her military clothes and the spear in her hands. In Cartari Virtù maschile is similarly described, adding a turtle under one foot (as in n. 28, pp. 369-70), which Ramos changes into a pair of anchors, a sign of stability which was no doubt derived from Valeriano (as in n. 29, $\mathrm{xlv}$, fol. $536^{\mathrm{r}}$ ).

\begin{abstract}
50 Agustín (as in n. 29), Diálogo II. Agustín only says that Spes has a plant in her hand. Still, the lily-which would flower again even if the plant had withered-is associated with Hope by Pliny, Natural History, xxi.22, from where Valeriano took it (as in n. 29, lv, fol. 402r). 51 The two clasped hands, cornucopia and caduceus standing for harmony and prosperity are familiar symbols in books of emblems. Lançina draws on Valeriano (as in n. 29, lix, fol. $429^{\mathrm{v}}$ for the caduceus, and lvi, fol. $408^{\mathrm{v}}$ for the cornucopia), and from Agustín (as in n. 29, Diálogo II, p. 44), where both elements are brought together to indicate that abundance follows from peace and concord. For Cartari, peace and concord are one, represented by a beautiful woman carrying cup and cornucopia (as in n. 28, p. 317); for him it is Felicitas who carries caduceus and cornucopia (pp. 488-9).
\end{abstract}


señora infanta'. This phrase, which seems to suggest the possibility of a marriage between the Infanta (later queen of France), who was then just six years old, and a member of the Austrian dynasty, could refer to one of those projects conceived in order to consolidate some particular political interest which later became irrelevant. ${ }^{52}$ The distinction that such a union would give the Habsburg family was celebrated in two hieroglyphic images (Fig. 61, no. 12). Venus's girdle, covered with fleurs de lis, symbolised loving sentiment. The signs of the Zodiac, Leo and Virgo, the former for the Infante, the latter for María Teresa, who was born under Virgo, augured a radiant future for the subjects of both crowns (Appendix IIc, Hieroglyphs 23-4).

The uniformity of political and religious interests between the two Habsburg branches was illustrated by sculpted figures of Spain and Austria in similar attire and attitude; hand in hand and joined by a military sash, they occupied the central place, easily visible, in this second level of the catafalque. Two globes at the feet of Spain indicated the universality of her domains, while the two-headed eagle of Austria symbolised ancient imperial grandeur. Thus the university programme depicted the Spanish Habsburgs, with their territorial possessions, as protectors of their Austrian relatives, holders of the imperial title.

Spain's dress is described in some detail and appears to adapt the attributes of Italy and Rome in Agustín's Diálogos de medallas. From the representation of Italyconsidered as the geographic seat of the empire-Ramos del Manzano took the crown of 'turrets and ramparts' and the sceptre in the right hand; while the two worlds beneath Spain's feet replace the single globe depicted on the coin of Italy in Agustín's book: if Italy had possessed one empire, Spain reigned over two. From the figure of Rome he chose, as a symbol of strength and virtue, the parazonium, distinctive weapon of the Greek and Roman armies-which Ramos del Manzano, with absurd vanity, claimed had been derived from Spanish models, since its shape, short and curved, recalled the alfanje (Spanish cutlass); although in fact the parazonium was straight. ${ }^{53}$

The funeral pyres of the Roman emperors, and of the empresses who had participated in government, were surmounted by an eagle to bear their spirit to the heavens. The catafalques of imperial consorts gave this role to a peacock, attribute of the goddess Juno, the prototypical wife and mother. ${ }^{54}$ It was therefore not inappropriate that the university pyramid should have crowned its third tier with an eagle which would carry Isabella's soul, another symbolic lily, to paradise (Fig. 61, no. 13).

The university programme culminated in a great crown (Fig. 61, no. 14) under which the king and queen bade farewell. The crown does not allude here to the biblical notion of recompense for the deceased (Proverbs 4.9, Timothy 4.8), as was usual. The motif chosen by the Salamanca scholars captures the two basic principles of the political theory of the age: the indivisibility of the state and the perpetuity of the monarchy. Fearing that the demise of the monarchy and internal friction might give rise to a division of power which would rock the system, canon lawyers and statesmen had begun to prepare a legal corpus pervaded with mystical significance: God not only delegated to a single sovereign the capacity to govern the destiny of a nation, but chose

\footnotetext{
52 The sudden death of her brother Baltasar Carlos on 9 October 1646 made María-Teresa the heir to the Spanish monarchy. From that time, Mazarin began to consider the possibility of a union between the only daughter of Philip IV-to whose hand the Archduke Leopold William also aspired-and Louis XIV. The marriage was finally celebrated in 1669 . K. Justi, Velázquez y su siglo, Madrid 1953, pp. 674-80.
}

${ }^{53}$ Agustín (as in n. 29), Diálogo III, pp. 98-9.

54 Valeriano (as in n. 29), xxiv, fol. $171^{\mathrm{v}}$, undoubtedly consulted by the designer, indicates that this rule excluded the empress Faustina, 'quae viro ipsa dederit imperium'. 
to endow regal dignity with an everlasting existence which transcended the lives of successive individuals. ${ }^{55}$

\section{UNIVERSIDAD DE SALAMANCA}

\section{APPENDICES}

Extracts from Luis Félix de Lançina y Ulloa, Relación de la funeral pompa en las honras que hizo la muy insigne Universidad de Salamanca ... a la buena memoria de la reina ... Isabel de Borbón, with commentary. ${ }^{56}$ Appendix I is intended to give some sense of the literary qualities of the text. The first item is also useful in assessing the role of Lançina. Full translations have not been attempted, but the brief paraphrases should convey the main ideas. Appendix II is devoted to transcribing the most significant passages of the twenty-four hieroglyphs and investigating them more fully than in the main text. Considering that the authors had hardly more than a month to devise the programme, their achievement is impressive. Nevertheless, for all the political originality of the overall scheme, individual components and motifs were part of the standard scholarly repertory of the age, and it has not been difficult to find a few correspondences in emblematic imagery (Figs 64-8).

Ia: Ramos and Lançina (folio $43^{\mathrm{v}}$ )

El docto, y grave ornato de historias, figuras, emblemas, jeroglíflicos, letras y versos, en quien misteriosamente a un tiempo se cifraron y descifraron los varoniles hechos y heroicas virtudes de la Reina... que el cielo goza ... corrieron por cuenta de la amena y grande erudición del doctor Francisco Ramos del Manzano, del Consejo de su Majestad en el secreto y su Presidente en el extraordinario de Milán. $\mathrm{Y}$ aunque mi cortedad les ha dado a la estampa menos adornados de lo que pudieran salir del rico prontuario de su doctrina, con todo (no sea mi inclinación a todo género de buenas letras, escándalo a la envidia esta vanidad), a permitirlo lo estrecho de los márgenes bien llegase a fiar de mi diligencia que los diese más noticiosamente de lo que van ataviados.

[The histories, figures, emblems, hieroglyphs, inscriptions and verses that ciphered and deciphered the 'manly deeds' and 'heroic virtues' of the queen were the work of the erudite scholar Ramos. Due to my shortcomings, I consign them to print in a less elegant form than I would have wished. As a lover of fine literature, I would happily have provided a fuller version, had the narrowness of the margins allowed it.]

\section{Ib: The sonnet and its context (folio $24^{\mathrm{r}-\mathrm{v}}$ )}

Volvía el tercer lienzo del túmulo a hacer frente a la puerta de las cadenas... la tercera inscripción o elogio fúnebre en un Soneto a quien pudiera confiadamente haber dado el Autor (a no ser su modestia sobradamente mal contentadiza en este género de composición) mejor lugar que el que tuvo debajo de la escalera que daba paso al túmulo y corredor de la Universidad, pero él sobresalió tanto y se le hizo tan bueno en la atención y juicio de todos, que aunque desempeño muy bien el crédito de quien le hizo, deshizo también con los aplausos que se granjeó muy a su satisfacción, el agravio que en darle aquel lugar se le había hecho.

$$
\begin{aligned}
& \text { De la lis de Isabel, Fenix lucida, } \\
& \text { peregrino este túmulo, esta llama } \\
& \text { urna es y pira o tu lirios derramas } \\
& \text { de este lirio a urna y pira esclarecida. } \\
& \text { De amor y afán la fiebre más crecida } \\
& \text { que le agostó florido, hoy más le aclama, }
\end{aligned}
$$

55 This form of political thought was developed by
Diego Saavedra Fajardo, Empresas politicas, Milan 1642,
empresa LXX. The transfer of spiritual concepts to poli-
tical power as well as the concept of continuity of the
dynasty, albeit applied to the medieval world, have been studied by E. H. Kantorowicz, The King's Two Bodies: a Study in Mediaeval Political Theology, Princeton 1957, pp. 314-16.

56 Transcribed (with updated spelling) from the copy in the National Library in Madrid, no. 3/60263. 
pues si rindió la vida a mejor fama, de la fama renace a mejor vida.

Fenix y flor, Escuela Real previene a flor y Fenix real, urna y hoguera, flor ya de luz mayor, fenix de vuelo.

Ninguna en inferior mansión cupiera que ella en el cielo, luz y vuelo tiene,

y ésta se erige en urna y pira al cielo.

[There was a sonnet to which its Author-had he not been so modest and self-critical-could have accorded a much better place than he did: under the stairs [Fig. 61, no. 3]. But the poem was so acclaimed that the offence of hiding it away was undone.]

The second stanza of the sonnet is the only one that lends itself to an almost word for word translation: 'From love and labour the rampant fever/ that dried the flower, now celebrates it the more/ for if it surrendered life to better fame,/ from fame it is reborn to better life'.

\section{Ic (folio $43^{\mathrm{r}}$ )}

Y no fue intempetuoso ni reprehensible que con el simulacro de la reina N.S. (cuyas honras se hacían) se pusiese también el de su esposo y rey N.S. que Dios guarde, porque aunque no abonan esta resolución, el rito antiguo o lugares de Apiano y Polibio, con todo el amor grande que su majestad tuvo a su esposa, pudo calificarle a la Universidad en el juicio de todos su modo de sentir y asegurarla de la calumnia impertinente de cualquiera menos considerada censura ... y así fue acierto muy hijo de la consideración, reconociendo que el Rey N.S. no negaría a las persuasiones de su voluntad y a las instancias de este gremio a ser posible el glorioso realce de su asistencia en estas honras, poner su imagen para que en vez de su persona, las diese majestad y mayor lustre.

[Putting the effigy of the king next to that of the queen was 'neither out of place nor reprehensible'. Even if unsupported by ancient precedent, this decision was justified by the king's great love for his wife, which would have made him wish to add the 'glorious enhancement of his presence at these celebrations, through his image if not his person...']

\section{Id (folio $44^{\mathrm{r}}$ )}

Crecía por instantes el concurso y con la espaciosa detención a que obligaba lo mucho que tuvo que admirar (la compostura del túmulo), el aprieto y en él a pesar del ahogo, los desahogos que suele ocasionar el tumultuario vaivén de la multitud. Bien sentidos, de maltratados, salieron del conflicto los sobradamente embarazosos trajes de algunas damas que impensadamente se hallaron engolfaldas en la alta mar de aquel proceloso bullicio, sin que pudiese valerles contra el ultraje de sus inquietas olas, la reverencia de su ser, el sagrado del respeto que siempre las defiende. Entonces califiqué por grande la cauta providencia de los romanos que (recelosos de semejantes accidentes), prohibieron rigurosamente que sus matronas asistiesen a estas fúnebres celebridades aunque no apruebo la demasiadamente escrupulosa temeridad de Publio Sempronio que repudió a su mujer por la transgresión de esta costumbre.

[There was so much to admire, and at times the crowd grew so dense, that for some overdressed ladies 'the reverential respect that always protects them' was of no avail against the buffeting of the human waves. It was with accidents of this sort in mind that the Romans forbade ladies at such funeral, though Publius Sempronius went too far in divorcing his wife for transgressing this custom.]

IIa: Hieroglyphs 1-8, positioned on either side of the pictorial scenes on the lowest tier of the pyramid (Fig. 62, nos 1-4)

\section{Hieroglyph 1 (folio $21^{\mathrm{r}-\mathrm{v}}$ )}

Se pintaba un león coronado (armas de nuestro rey y de sus reinos), salía de la boca del león un lirio o flor de lis (blasón de la corona de Francia y de sus reyes) y parecía estaba libando el lirio un enjambre 
de abejas, símbolo de la unión y dulces frutos de la paz que mediante la [folio $21^{\mathrm{r}}$ ] fortaleza de aquel león y dulce agrado de esta flor de lis, amablemente unidas gozaron algún tiempo los vasallos de ambas coronas. Era la letra de este jeroglífico la del enigma que Sansón propuso a la juventud de Palestina sobre el caso del panal hallado en la boca del león De forti dulcedo...

Opposite the Hall of Rhetoric (Fig. 62, no. $1)$, next to the painting of the double marriage. ${ }^{57}$ The motto is from Judges 14.14, 'Et de forti egressa est dulcedo'. Samson's riddle is often found in emblematic literature; $;^{58}$ and the beehive representing the sweetness and harmony of peace is also a topos. The swarm of bees around the lion's mouth represents prosperity in a country upheld by firm government, according to Diego Saavedra Fajardo's Empresas políticas (Fig. 64) ${ }^{59}$ In the university's programme, the crowned lion with a lily in its mouth represents the alliance of the French and Spanish houses with the wedding of Philip and Isabella, and the swarming bees announce its happy outcome.

\section{Hieroglyph 2 (folio $22^{r-v}$ )}

Retratábase en medio ... la ciudad de Troya, guarnecida de aquellos muros y torreones que



Fig. 64-Diego Saavedra Fajardo, Empresas políticas, Milan 1642, folio 724, empresa IC

Biblioteca Nacional, Madrid por concierto hecho con Laomedón, su rey, creyó la antigüedad que habían fabricado Apolo y Neptuno: y que después los mesmos y sucesivamente Hércules, los infectaron y destruyeron en pena del perjurio y fe violada por Laomedón y su ciudad a estas deidades. Representábase sobre la ciudad y en la parte superior del cuadro, Apolo con arco y flechas como que las arrojaba de pestilencia en aquel pueblo y en la parte inferior del lienzo, a un lado Hércules con su piel de león y clava o maza en las manos amenazando a la ciudad y de la otra parte, en un brazo de mar, Neptuno.... acompañado de tritones, en la mano siniestra un delfín y en la diestra el tridente con que hería aquellos infieles muros. Era la letra Non est pax impiis. Mostraba la misma que a la impiedad de Troya hacían justa guerra los elementos del aire, agua y tierra y para insinuación de la semejanza con que la Rochela a la traza que Troya como impía e infiel a Dios y a hombres, fue castigada por el Hércules francés Luis XIII y por nuestro cuarto planeta y sol de España Philipo, por mano de su Neptuno el Toledo.

Positioned opposite the Hall of Law (Fig. 62, no. 1), next to the illustration of the defeat of the Huguenots at La Rochelle. ${ }^{60}$ The author explains the ancient parallel: the destruction of Troy as a punishment for the perjury of Laomedon towards the gods who had helped him to build the city walls. The story was mentioned in Vergil's Aeneid (iv.542) and told in detail in Ovid's Metamorphoses (xi.200-20). La Rochelle, that nest of heretics, was brought to submission through the combined attacks of Apollo (Philip IV) from the heavens, Neptune (Fadrique de Toledo) from the sea and Hercules (Louis XIII) from the land. It is more than likely that Ramos del Manzano drew on the well-known mythological manual by Juan Pérez de Moya,

57 This painting is discussed above, p. 178.

58 For example, in Valeriano (as in n. 29), xxvi, fols $187^{\mathrm{v}}-8^{\mathrm{r}}$

${ }^{59}$ Alciati proposes a helmet turned into a beehive to denote peace after war: Los emblemas de Alciato traducidos en rhimas españolas por Bernardino Daza Pinciano (Lyons 1549), facs. edn Madrid 1975, p. 99.

60 For the painting see above, p. 178. 


\section{MORALIZADAS. 77 Teipfum, de te ipjo. \\ A timermo,detimefmo.}

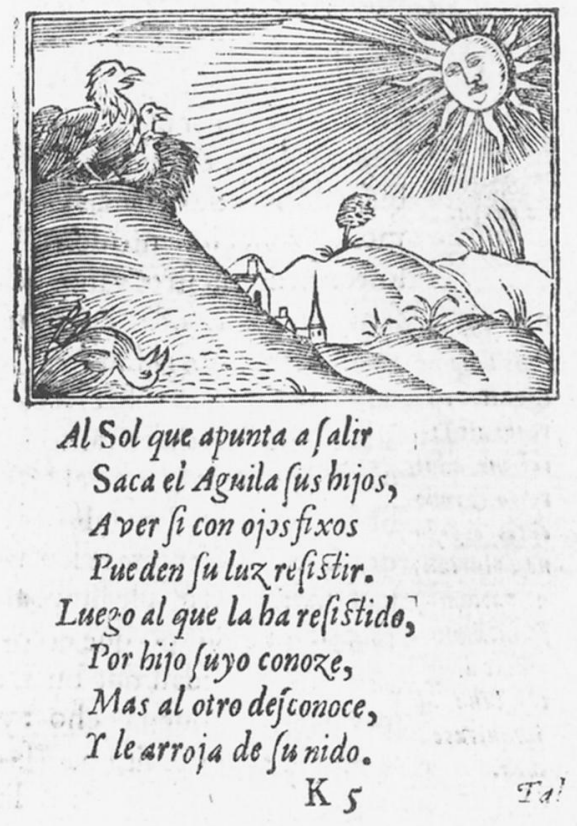

Fig. 65-Hernando de Soto, Emblemas moralizadas, Madrid 1599, folio $77^{\mathrm{r}}$

Biblioteca Nacional, Madrid
Philosophia secreta, which states (xiii.1) ${ }^{61}$ that Neptune, 'made the waters of the sea flood over the city' ('hizo que las aguas del mar bañasen la ciudad'), that Apollo 'sent a plague' ('envió pestilencia') and Hercules 'made war against Troy ... killing Laomedon and many other Trojans' ('movió guerra contra Troya ... matando a Laomedón y a otros muchos troyanos'). The story of Laomedon often served as a moral tale for men who failed to keep their word. Still, if the siege of Troy was a punishment for the deeds of the city's founder, it could also have a positive connotation, as for example in Hernando de Soto's Emblemas moralizadas, where it demonstrates the patience of the Greeks. ${ }^{62}$

\section{Hieroglyph 3 (folio $23^{\mathrm{r}}$ )}

Se dibujaba un aguila real coronada sobre un risco, tenía entre las uñas un rayo y a un lado un aguilucho o hijuelo pequeño cuya vista parecía que examinaba haciéndole mirar de hito en hito al sol que se mostraba en lo alto del cuadro... Veíase también en lo alto en una nube a Júpiter desnudo, coronado de hojas de encina, en la siniestra mano tenía un cetro y la diestra desocupada la extendía para recibir dos rayos que le llevaban en las uñas dos aguiluchos que iban como volando hacia la nube.

Era el concepto todo de Claudiano en la prefación al panegírico del tercer consulado de Honorio. La letra decía Alit, armat, explorat. Y por bajo de todo descifraban el jeroglífico... aplicaban el oficio de Aguila a la reina que armaba, ejercitaba, remitía ministros y rayos de España al Júpiter de ella.

Facing the stairs of the cloister (Fig. 62, no. 2) and associated with the scene of the queen and prince visiting the armies in Catalonia and Extremadura ${ }^{63}$ The comparison of the eagle with royalty was extremely common in emblematic literature. ${ }^{64}$ The legend that the eagle expels from its nest any eaglet unable to look into the sun is recorded, for example by Hernando de Soto (Fig. 65), Juan de Horozco y Covarrubias and Sebastián de Covarrubias y Orozco. ${ }^{65}$

Lançina quotes Claudian's preface to Panegyric on the Third Consulate of Honorius as his source for this hieroglyph. ${ }^{66}$ The three verbs of the motto ('Alit, armat, explorat') are also taken-though out of context-from that text. The eagle as Jupiter's servant, with his weapon, the thunderbolt is often found in political emblems (Fig. 66) ${ }^{67}$ here of course Jupiter is Philip IV.

61 Juan Pérez de Moya, Philosophia secreta (1584), ed. E. Gómez Baquero, Madrid 1928, pp. 213-14.

62 Hernando de Soto, Emblemas moralizadas, Madrid 1599 , fols $15^{\mathrm{v}}$.

63 See above, p. 178.

64 Valeriano (as in n. 29), xix, fols $138^{\mathrm{v}}-9^{\mathrm{v}}$ (Imperatoria maiestas).

65 Juan de Horozco y Covarrubias, Emblemas morales, Segovia 1589, p. 41; Sebastián de Covarrubias y Orozco,
Emblemas morales, Madrid 1610, no. 79. See also R. Wittkower, 'Eagle and Serpent: A Study in the Migration of Symbols', this Journal, ii, 1938, pp. 315-16, n. 3.

66 See the edn ed. M. Nisard, Paris 1855 , p. 583.

67 See also Saavedra Fajardo (as in n. 55), empresa XXII, fol. 146. 


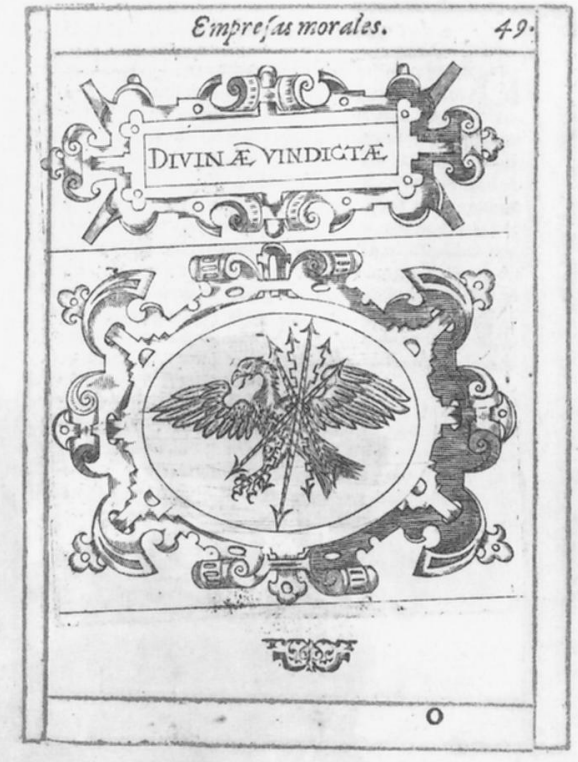

Fig. 66-Juan de Borja, Empresas morales, Praga 1581, folio $49^{r}$

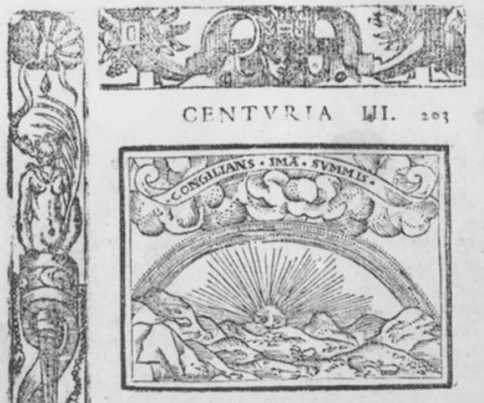

EMBLEM A. 3.

Aquel cele flial arco, que locando

Conambaspuntasa raiz del Jucio.

Sube, fucorbalinealewantardo

Sobre las nubes al Impireo crelo:

Con lo alto, lo buxo va igualando,

Señal cierta de pazuy de con fuelo,

A la puefia del fol, que en el $\int e p u f o$,

Quando el müdo quedóciego y cófulo.
\[ \mathrm{Dd}_{3} \mathrm{El} \]
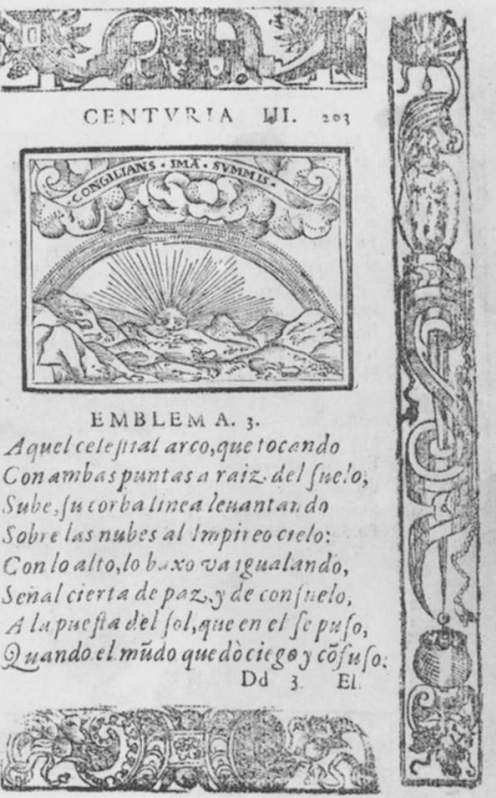

Fig. 67-Sebastián de Covarrubias y Orozco, Emblemas morales, Madrid 1610, centuria iii, p. 203

Figs 66-7: Biblioteca Nacional, Madrid

\section{Hieroglyph 4 (folio $23^{\mathrm{v}}$ )}

Daba vida a este lienzo... un iris o arco celeste entre nubes con la variedad de colores que le ilustran y por bajo del arco una mujer hermosa coronada de lirios, con ropaje o tunicela cambiante y en la diestra


aludió el emblema a los admirables efectos del iris o arco celeste, señal dada por Dios de paz y serenidad después de la mayor tormenta y a los del lirio (llamado iris por lo que se parece al celeste en la variedad de colores) cuyo jugo y olor tiene virtud para corregir vicios del aliento, causa que por ventura tuvo Homero para fingir [folio $24^{\mathrm{r}}$ ] que los oradores o embajadores de Troya habían gustado de este lirio, haciéndole así símbolo del labio de la elocuencia... como también por esta causa fue símbolo de la elocuencia la Iris celeste... y una y otra flor y arco, copia bien que inferior del agrado y superior elocuencia con que nuestra iris y Lirio Real animaba a las mayores empresas y reinaba en los corazones.

Facing the entrance to the chapel (Fig. 62, no. 2), Hieroglyph 4 corresponds to the painting showing the queen as ruler of the realm. ${ }^{68}$ Since the queen was a Bourbon it was quite natural to associate her with the fleur de $l y s,{ }^{69}$ and hence with the flower and Iris, goddess of the rainbow. For his floral image, Ramos del Manzano relied on Pliny, who attributes to the plant a particular efficacy in purifying and sweetening the breath (Historia naturalis, xix and xxi.1-2), thus making the flower a symbol of eloquence; and no doubt also on Valeriano. ${ }^{70}$ Vergil, in the closing lines of Aeneid, iv, and Ovid, in Metamorphoses, i.270-1 and xiv.85, describe Iris in flight, dressed in many colours, as messenger of Juno (here associated with the queen). For emblematists the rainbow was often the symbol of reconciliation; here the authors of the university programme may have drawn on the Emblemas morales of Sebastián de Covarrubias y Orozco (Fig. 67). 
Hieroglyph 5 (folio $25^{\text {r-v }}$ )

Se mostraba Minerva (deidad creida tutelar igualmente de armas y letras) con insignias de ambas funciones, yelmo en la cabeza y sobre él corona de oliva, en la diestra una pluma y en la siniestra un escudo de cristal y grabada o entallada en éste la cabeza de Medusa ..., parecía que hacía amago o ademán de mostrar el escudo y aquella sangrienta cabeza al Layan Palante, rebelde opuesto con los demás terrígeras al imperio de Júpiter a quien Minerva armada asistía... [folio $25^{\mathrm{r}}$ ] Era la letra de Claudiano en su Gigantomaquia... Adspectu contenta suo, non utitur hasta. Y aunque no parecía necesaria la aplicación del emblema a la Universidad de Salamanca, real Minerva del Júpiter de España, en cuyo obsequio triunfó de los terrígeras rebeldes a su corona en la fuga con que desampararon el sitio del Gardón.

This hieroglyph, placed opposite the second hall of Law (Fig. 62, no. 3), symbolises the defence of the city of El Gardón by members of the university. ${ }^{71}$ El Gardón is a small town in the province of Salamanca, next to the Portuguese border. In a very minor battle some troops sent by the university repelled an attack from rebels against the crown. Minerva (the university) forces the giant Pallas (the rebels), who has defied Jupiter (Philip IV), to flee. The monstrous aspect of the giant, who is described in the Relación as having 'legs ending in coiled serpents', is standard (e.g. Ovid, Metamorphoses, ii.163-252). As mentioned by Lançina, both the hieroglyph and its motto applied to Minerva with her gorgoneion are taken from Claudian's Gigantomachia. ${ }^{72}$

\section{Hieroglyph 6 (folios $26^{r}-7^{r}$ )}

Se dibujaba a la parte del occidente una palma y a la del oriente un laurel ... inclinados el uno al otro. Pendían de cuatro ramas de la palma, todas inclinadas al laurel, cuatro coronas de oro, las dos con puntas [folio $26^{\mathrm{r}}$ ] como de almenas o torrecillas de muro que por esto llamó murales o turritas la antigüedad romana y premió con ellas a los primeros expugnadores de ciudades sitiadas. Y las otras dos con puntas de baluartes pequeños de fortificaciones de reales que llamó también la misma antigüedad vallares y castrenses, y fueron siempre premio y honor de los que en batallla ganaron los reales enemigos. Pendía también del laurel y de una de sus ramas inclinada a la palma, otra corona de hojas de encina a quien dió Roma nombre de cívica porque se concedía solamente a quien redimía de la muerte (que podía ejecutar el enemigo) otro ciudadano, parecía que con natural propensión se ofrecían palma y laurel recíprocamente estas coronas y que la palma, símbolo conocido de las victorias y no menos del amor conyugal..., estando distantes se buscaban y procuraba acercarse con recíproca inclinación de sus ramas, era igualmente símbolo de la reina que desde el occidente de Madrid victoriosa y amante ofrecía al laurel de Apolo y del cuarto planeta Felipe, esposo suyo ausente en el oriente de Cataluña, el oro de su fe y amor en las dos coronas murales de la expugnación de Monzón y Lérida y las dos castrenses de las batallas campales de Montijo y Segre que en igual correspondencia nuestro laurel rotornaba a esta palma real, la corona cívica... [folio $26^{\mathrm{v}}$ ] de la salud pública de estos reinos ... era la letra de Sidonio Apolinar en el panegírico a Maiorano César Crinenque, sacrum tibi more priorum nectet muralis vallaris civica laurus.

This hieroglyph was opposite the Hall of Medicine (Fig. 62, no. 3), next to the paintings representing the victories of Monzón, Lérida and Montijo. ${ }^{73}$ The tower-crowns (turritas), symbols of captured cities, perhaps came from Agustín's Diálogos de medallas. ${ }^{74}$ The corona civica as a Roman military reward is mentioned, for example, in Pliny (Historia naturalis, xvi.3). The palm tree with its branches leaning west-Philip IV was away in Catalonia at the time of Isabella's death-signifies the love of the late queen for her husband, drawing from a famous passage of Pliny (xiii.7), paraphrased in Valeriano's Hieroglyphica, ${ }^{75}$ which claims that female palms seek males to be fertilised. ${ }^{76}$ The motto is derived literally from Sidonius Apollinaris's Panegyricus Iulio Valerio Maioriano Augusto dictus (Carmina, v.587-8), in the Opera of Sidonius Apollinaris (Paris 1614).

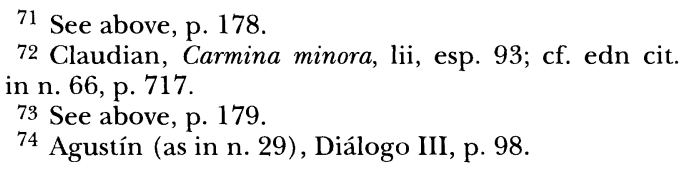

${ }^{71}$ See above, p. 178.

72 Claudian, Carmina minora, lii, esp. 93; cf. edn cit.

73 See above, p. 179.

74 Agustín (as in n. 29), Diálogo III, p. 98.

75 Valeriano (as in n. 29), 1, fol. $370^{\mathrm{r}-\mathrm{v}}$ (Nuptiae).

76 For this theme and its use in royal allegories, especially in France, see D. Watkin, 'Iungit amor: Royal Marriage Imagery in France, 1550-1750', this Journal, liv, 1991, pp. 256-61 and pls 70-3. 


\section{Hieroglyph 7 (folios $28^{\mathrm{v}}-9^{\mathrm{r}}$ )}

Se retrataba una nube y dentro de ésta, una columna luciente a cuyos reflejos goteaba de la nube algún rocío sobre un vellón de lana o vellocino que extendido en la tierra le recibía. Pintábase también a una parte del vellón, una mano con una concha como que iba a llenarla de aquel rocío que recogía el vellocino. Fueron nube y columna, alusión a las que sirvieron de guía en el desierto al pueblo de Dios y ambas sombras sagradas de aquel Señor Sacramentado, que debajo de nube y velo de cándidos accidentes, es columna de luz... fueron también vellón y rocío, alusiones de aquel vellón misterioso que señalado a Gedeón juez y mayor caudillo del pueblo de Israel por prenda de las asistencias divinas en su favor ... y fue también imagen y símbolo de la Virgen Santísima ... y últimamente, la mano y concha codiosa de enriquecerse de aquel celestial rocío, cifra no obscura de la piedad y afecto con que la reina ... con celo no inferior al del otro caudillo hebreo en los dos octavarios [folio $28^{\mathrm{v}}$ ] ... participaba de aquella nube y columna de luz por medio de este virginal vellocino ... la letra ... del libro de los Jueces. Si ros in solo vellere fuerit sciam quod per manum meam liberabius Israel, et expresso vellere concham rore implevit.

This hieroglyph was placed opposite the Hall of Canon Law (Fig. 62, no. 4) and corresponded to the scene in which the queen was at prayer in the palace chapel. ${ }^{77}$ The motto is a summary of Judges 6.37-8, 'si ros in solo vellere fuerit et in omni terra siccitas, sciam quod per manum meam sicut locutus es, liberabis Israel. Factumque est ita. Et de nocte consurgens expresso vellere concham rore implevit.' The emblem is based on Exodus 13.21, in which God leads the people of Israel across the wilderness of the Red Sea, by day in a column of cloud and by night in a column of fire, and Judges $6.36-8$, the episode of the fleece which confirmed Gideon as the liberator of his people. The column in the cloud stands for God, the fleece receiving the dew is a famous Marian figure, and the hand holding a shell represents the queen's piety. ${ }^{78}$

\section{Hieroglyph 8 (folios $29^{\mathrm{v}}-30^{\mathrm{r}}$ )}

Pintábase a una parte a la diosa Juno coronada de lirios con ropaje o tunicela cambiante, símbolo del elemento del aire a que esta deidad preside. Tenía entre los brazos a Hercules o Alcides niño a quien franqueaba engañada el pecho y destiladas de éste algunas gotas de aquella sangre, que en desmentido color es alimento en la primera edad a los mortales, daban ser y blancura a un lirio que estaba dibujado a sus pies. Pintábase a otra parte Venus coronada de rosas y cubierta de un cendal o velo azul transparente, parecía que volando al socorro de su querido Adonis y poniendo incautamente los pies en las espinas de un rosal blanco y dejaba aquellas rosas, antes cándidas ya purpúreas con el matiz costoso de su sangre ... Eran como ... [folio $29^{\mathrm{v}}$ ] resunta de una y otra fábula, estas letras Juno liliaca, Venus rosea. Y era la semejanza ... que así como a la vida de este lirio real debió el siglo candores de felicidades, debe hoy a las rosas de sangre que rubricó la muerte en sus labios, el negro luto y lágrimas en que se sepulta esta pérdida.

By the entrance to the Hall of Theology (Fig. 62, no. 4), next to the paintings representing the victories of Balaguer and Tarragona. To represent what the life and death of the queen meant for Spain, Ramos del Manzano drew his mythical analogies from Cartari, who follows Vergil in depicting Juno crowned with lilies and dressed in a 'tunicela cambiante', symbol of the air. While suckling Hercules the goddess spilt some drops of milk that became lilies, which the ancients called Juno's roses. Venus, when once hurrying to help Adonis, was pricked by a white rose, which turned red from her blood. Valeriano, in his encyclopaedia, likewise describes the episodes. ${ }^{79}$

77 See above, p. 179.

78 A suggestion due to Elizabeth McGrath is that the emblem actually alludes to Sapientia, from Ecclesiastes 24.7, 'et thronus meus in columna nubis', a passage regularly associated with the Virgin. This may be an interesting example of how Lançina perhaps did not entirely undertand every detail of the programme, but was adding his own references.

79 The connection between Juno and air seems to come from the handbook attributed to Albricus. See
Mythographi latini, ed. A. Van Staveren, Leiden and Amsterdam 1742, p. 918 (xi, De Iunione); and Lucius Annaeus Cornutus or Phornutus, De natura deorum. Cartari provides the stories concerning Hercules and Adonis (as in n. 28, pp. 190-1, 536-7), as well as the inspiration for the mottoes. The same stories are in Valeriano (as in n. 29), lv, fols $400^{\mathrm{v}}-1^{\mathrm{r}}, 402^{\mathrm{v}}$. 
IIb: Hieroglyphs 9-16, located on the pedestals of the columns (Fig. 62, nos 5-8).

\section{Hieroglyph 9 (folio $31^{\mathrm{v}}$ )}

Dibujóse ... un águila real (ave y ministro conocido de Júpiter) sobre un castillo (arma de nuestro rey y de sus reinos) con una flor de lis en el pico, símbolo de la reina y de su real casa de Francia y en la antigüedad flor consagrada a Juno consorte de Júpiter y a todas estas luces águila, flor de lis y castillo, sombras no oscuras de la unión conyugal de estas dos majestades. Decía una letra latina Flos Iunionius [recte Iunonius] et Iovis ales, y otra castellana al Cesar de España al Joven Novelo.

This hieroglyph was placed on the first pedestal (Fig. 61, no. 5). The union of the houses of Austria and Bourbon is symbolised in a combination of motifs already used in the tier below: eagle, castle and lilies. The motto is from Valeriano. ${ }^{80}$

\section{Hieroglyph 10 (folio $31^{\mathrm{v}}$ )}

Se pintó una hermosa azucena plantada entre espinas, sagrado emblema de la inocencia y cándida pureza de la reina entre las espinas y riesgos de la majestad y del siglo. La letra Sicut lilium inter spinas.

Also on the first pedestal. The attribute of the bride of the Song of Songs, 'like a lily among thorns' (2.2), is used as a metaphor of virtue in a number of different sources, especially in emblems of pious content, such as the Emblemes ou devises chrestiennes of Georgette de Montenay (Fig. 68).

\section{Hieroglyph 11 (folio $31^{\mathrm{v}}$ )}

Se dibujó una flor de lis y sobre su copa un corazón coronado, retrato éste del rey como la flor de aquella lis, de cuyo amor y celo fió su corazón su esposo y el peso de sus mayores cuidados. La letra Confidit in ea cor viri sui.

(Fig. 61, no. 6) The crowned heart represents the king supported by the love of his spouse. The motto is from Proverbs 31.11, on conjugal affection.

\section{Hieroglyph 12 (folio $32^{\mathrm{r}}$ )}

Se pintaba una espada sembrada pomo, cruz, empuñadura y corte, de flores de lis como la que entregan en Francia sus reyes al condestable recién electo...Pintábase también un cetro de cuyo remate y cima salía una flor de lis de la manera que la usaron en la antigüedad los reyes de los caldeos, a la traza que describe Prudencio, el cetro de la sabiduría y vara o báculo de Aarón florecido de azucenas y rosas. Eran espada y cetro liliatos, símbolos claros de la excelencia del caudal de la reina ... en las materias del gobierno de paz y guerra... letra Nec Salomon in Omni gloria sua. Valiéndose de la comparación que hizo Cristo por San Lucas y explica san Ambrosio de la gloria de Salomón a la hermosura de una azucena dando la prelación a ésta como parece debe darse a la de nuestra real flor de lis, igualmente gloriosa en el gobierno militar y político.

(Fig. 61, no. 6) The emblem involves symbols of power. It is particularly based on biblical passages describing divine election to a mission. Hieroglyph 7 featured Gideon and the fleece; we now have Aaron and the sacred rod that vindicated him as high priest (Numbers 17.1-10). The motto comes from Luke 12.27 (applied, famously, to the 'lilies of the field').

\section{Hieroglyph 13 (folio $32^{\mathrm{r}-\mathrm{v}}$ )}

Se pintó una azucena como que recibía rocío de una nube... La letra deducida de san Mateo decía Lilia neque laborant neque nent y el concepto que se divisaba era que como la azucena en el sagrado evangelio sirvió de ejemplo de la seguridad con que debe fiarse y reconocerce el socorrro de nuestras [folio $32^{\mathrm{r}}$ ] necesidades a la providencia divina.... Así nuestra azucena real debió y reconoció devotamente el desahogo de los mayores aprietos de esta monarquía y los buenos sucesos de ella a la misericordia y piedad de Cristo y su Madre Santísima, dedicando a aquel rocío celestial y a esta nube purísima, afectuosos octavarios en su real capilla y en la de Atocha.

80 Valeriano (as in n. 29), lv, fol. $402^{\mathrm{v}}$ (flos Iunonius). 
(Fig. 61, no. 7) Here the queen is likened to the white lily selected from the varieties of iris for its fragrance and beauty. Her confidence in God is recalled in the quotation from Matthew 6.28, again of the lilies: 'Non laborant, neque nent'; this formed the motto and echoed the verse from Luke in the preceding hieroglyph. ${ }^{81}$

\section{Hieroglyph 14 (folio $32^{\mathrm{v}}$ )}

Pintaron unos lirios que a trechos hermoseaban un prado ameno y entre ellos algunas ovejas paciendo, símbolo éstas en todas letras del pueblo humilde y necesitado como aquellos de aquella lis real de la reina, cuya piedad y caridad repartiendo largas limosnas por mano de su confesor, hizo del erial de las calamidades de este siglo, prado y pasto agradable de socorros a las necesidades mayores de sus vasallos, era la letra Pascitur inter lilia.

(Fig. 61, no. 7) The motto, from Song of Songs 2.16 ('he feedeth among the lilies'), seemed so appropriate that it was used in other funeral emblems for Isabella, for example in the exequies held for the queen in the convent of San Jerónimo in Madrid. ${ }^{82}$

\section{Hieroglyph 15 (folios $32^{\mathrm{v}}-3^{\mathrm{r}}$ )}

... se pintaba una urna o vaso sepulcral cristalino y

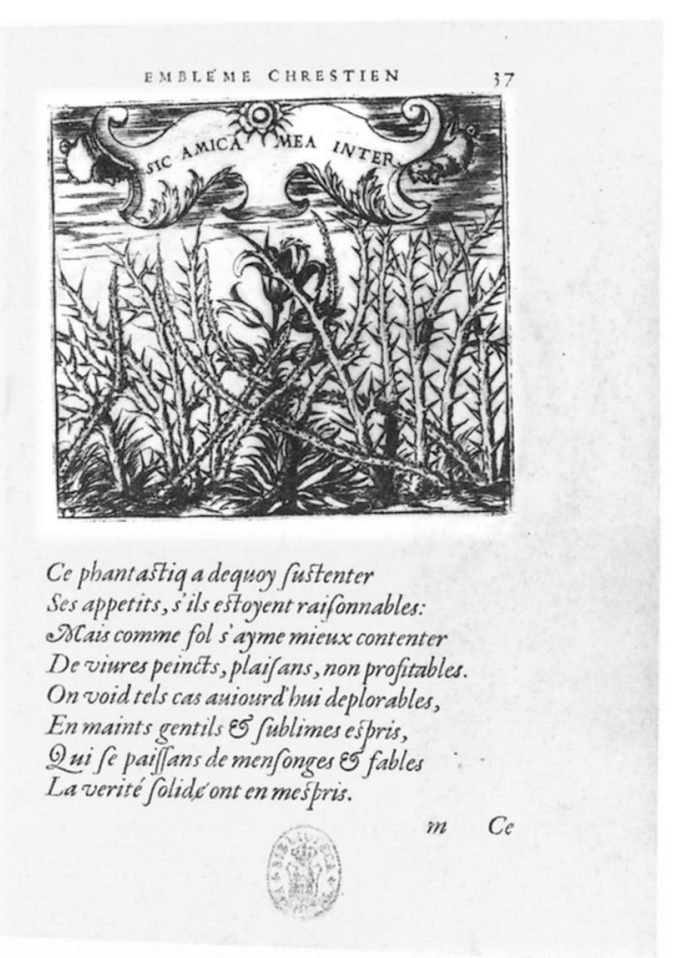

Fig. 68-Georgette de Montenay, Emblèmes ou devises chrestiennes, Lyons 1571, p. 37

Biblioteca Nacional, Madrid

sobre él una azucena de cuyo cogollo brotaban tres rosas purpúreas... letra del Príncipe de los poetas latinos con alguna (aunque poca) mudanza para la aplicación Mixta ornent urnam ut lilia terna alba rosa, talis moriens dabat ore colore. [folio $32^{\mathrm{v}}$ ] Conocido es el rito y antigüedad de esparcir flores y particularmente lirios blancos o azucenas y rosas en las urnas y túmulos de los difuntos y singular y menos conocida, la circunstancia de que fuesen de tres en tres las rosas que sirviesen de adorno al túmulo o urna, como lo da a entender una inscripción antigua en la ciudad de Como en el estado de Milán que traslada a la letra Piero y a la luz de estas suposiciones, y de la mezcla de azucena o lirio y rosa de que hizo tan debido aprecio y ponderación la mejor poesía, se descubre sin dificultad la alusión de este jeroglífico al accidente misterioso con que al expirar de la reina brotaron en sus labios tres gotas de purísima sangre como rosas que unidas aquel lirio real prevenían a su túmulo o urna decente ornato.

(Fig. 61, no. 8) The motto is a pastiche of Vergil, Aeneid, xii.68-9. Roman rites are again introduced to suggest thoughts about the death of the queen, and the signs of her last agony are endowed with redemptive value.

\section{Hieroglyph 16 (folio $33^{r-v}$ )}

Se dibujó una palma con los ramos tendidos e inclinados al oriente, emblema celebrado del amor conyugal por la natural propensión con que este árbol diferenciándose en los sexos, se apetece y busca recíprocamente, inclinándose la palma del sexo femenino a la parte en que está la del viril, aunque medie entre las dos algún río... [folio $33^{\mathrm{r}}$ ] Parecía pues que la palma retrato de la reina en el casto amor y firmeza inclinada al oriente de Cataluña donde estaba ausente su esposo, se marchitaba y consumía pero al mismo tiempo se veía pintado como que salía de la copa y cogollo de la palma y subía derecho al cielo, un lirio hermoso y lozano retrato también real de nuestra reina, prometiéndole con viva esperanza, entre aquella defunta marchitez candor, verdor y vida eterna. A la traza que esta planta

\footnotetext{
81 Valeriano (as in n. 29), lv, fol. 402 ${ }^{\mathrm{r}-\mathrm{v}}$ (Christus. Angeli).
}

82 Pompa funeral (as in n. 24), fol. $2^{\mathrm{r}}$ (hieroglyph II, located on the pedestal of the catafalque). 
aun después de cortada flor y tronco cuando parece que queda del todo seca, conserva oculta en su raiz virtud natural con que a su tiempo vuelve a florecer... razón que por ventura tuvo la antigüedad romana para usar de los lirios como de símbolo, el más propio de la esperanza... era la letra de este Jeroglífico... de Claudiano con variación de una voz, Spe maior, palma melior.

(Fig. 61, no. 8) Here again the idea is borrowed from Pliny, paraphrased by Valeriano, as quoted in Hieroglyph $6 .^{83}$ The contrast between the withering palm (the queen exhausted by the affairs of state) and the fresh lily is presented as a testimony to the immortality of Isabella's soul. ${ }^{84}$ As for the motto, Claudian writes in the third book of his Consulate of Stilicho: 'totus adest oculis, aderat qui mentibus olim, spe maior, fama melior ...' ${ }^{85}$

IIc: Hieroglyphs 17-24, on the upper tier of the catafalque (Fig. 62, nos 9-12).

\section{Hieroglyphs 17-18 (folios $37^{\mathrm{v}}-8^{\mathrm{r}}$ )}

Una flor de lis como que bajaba del cielo y otra como que subía de la tierra a él, alusión conocida la primera a las lises reales de Francia que bajaron del cielo en tiempo de Clodobeo... a ser empresa y armas de aquel [folio $37^{\mathrm{v}}$ ] reino y sus sucesores y la segunda, a nuestra reina en cuya alma dichosa subió al cielo a gozar de inmortal olor y verdor y se restituyó a su centro, la mejor flor de lis de aquel ramo. La letra decía Descendit ut ascendat.

Se pintaron los heliotropos flor y piedra. A una parte la flor girasol inclinada hacia el sol que estaba en lo alto y a otra parte, un vaso de agua y dentro de él la piedra también heliotropio o girasol, de color de esmeralda y en ella tres rayos o betas como de sangre. No hay cosa más notoria que la naturaleza de la flor girasol ni de mas pronta aplicación a la reina que en ausencia de su cuarto planeta y sol de España Felipe, inclinada toda al cielo, pasó a gozar su luz eternamente... a la traza que este real girasol de nuestra reina en las aguas de su mayor tribulación (eslo la muerte), hizo demostración de los rayos del amor de su sol y esposo Felipe en tres gotas de vivísima sangre que al expirar brotaron en sus labios. La letra por bajo de la flor girasol, decía Cum sole circum agitur y por bajo del vaso y piedra, In aqua solis radios sanguine mutat.

These hieroglyphs were located next to the queen represented as Immortality (Fig. 61, no. 9) ${ }^{86}$ In Pliny's Historia naturalis, xxii.57 and xxxvii.10, the heliotrope, both the flower and the blood-stone, when in water and under the sun's rays reveal red veins; this is here associated with the drops of blood that fell from the sovereign's mouth, making another image of the redemptive quality of her death. The mottoes are from Pliny, as noted by Lançina.

\section{Hieroglyphs 19-20 (fol. 39r)}

Cabeza de hombre con semblante... triste, ceñíale la frente una faja o venda negra dando vuelta a la parte opuesta o posterior de la cabeza y quedando pendientes a los lados de las sienes, dos puntas de la misma faja en quien se denotaba la diadema que sirvió de insignia real a los reyes de la gentilidad. La parte de la faja que cubría la frente, tenía estas letras Fasciam solue, multum mali sub illa latet. Ponderación de Séneca [Epistulae, lxxx.10] y primero de Antígono, para significar ... cuidado y congoja que paga una diadema y en la alusión del jeroglífico, propia de la tristeza y dolor de aquellar real cabeza. Veíase algo más alta la causa del dolor, que era una corona que remataba en puntas como de flores de lis y parecía se subía al cielo. El mote... Rapta est corona capitis nostri.

Se pintó una vara de azucenas y un báculo de quien salía una flor de lis, seña aquella del reino, como el profeta rey dijo y de la sucesión de él, destinada al Príncipe ... como el báculo del alivio y consuelo que en la infanta dejó la reina ... a su esposo. La letra era Virga tua et baculus tuus, ipsa me consolata sunt.

These were next to Philip IV, represented as Steadfastness (Fig. 61, no. 10) ${ }^{87}$ The mottoes are inspired by Lamentations 5.16, 'cecidit corona capitis nostri', and taken from Psalms 22.4, as noted in marginal notes in the text.

\footnotetext{
83 Above, p. 188.

84 For the idea of rebirth associated with the lily see above, n. 50.

85 Claudian, De consulatu Stilichonis, iii.5-6; cf. edn. cit. in n. 66, p. 636 .
}

\footnotetext{
${ }^{86}$ For this painting see above, p. 181.

87 See above, p. 181.
} 
Hieroglyphs 21-22 (folio 39v)

Un joven de poca edad y hermoso rostro con un rico collar o cadena al cuello, pendiente de ella el tusón y al parecer grabada en éste una flor de lis. Era el mote del sexto de la Eneida y aplicable con poca variación al Príncipe, esperanza de su heroico valor significadas en la flor de lis ... Nec puer austriaca quisquam de gente Philippos in tantum spe tollet avos.

En la segunda enjuta se pintó un balteo militar o tahalí esmaltado de flores de lis y mezcladas a trechos hojas de cardos a la traza que el lirio se describe entre espinas en las sagradas letras. De él pendía una cruz y esta letra Spes Hispaniae. Aludiose a la empresa de Luis II duque de Borbón que instituyó recién venido de Africa contra los moros, el órden militar y caballería de Santa María del Cardo con esta misma insignia o mote como refiere el P. Nicolás Causino.

These were next to Baltasar Carlos represented as Hope (Fig. 61, no. 11). ${ }^{88}$ Through the golden fleece and the lily-employed by the Romans as a symbol of hope for the fortunes of the Republic-Hieroglyph 21 expresses the faith of Isabella's Spanish subjects in the heir to the throne. Probably relevant is Pliny's claim that the lily blossoms even after the plant has dried. ${ }^{89}$ Hieroglyph 22 follows the same lines, relying on a reinterpretation of the motto chosen by Louis II the Good (1356-1410), Duke of Bourbon, for the military order he created upon returning from the disastrous crusade against Al-Mahdiya (near Tunis). ${ }^{90}$

\section{Hieroglyphs 23-24 (folio 40v)}

Una niña hermosa que tenía en la diestra una cintura sembrada de flores de lis, de la hechura del cíngulo o zona de Venus que llamó cesto la gentilidad y en quien reconoció vanamente virtud y fuerza de conciliar amor y cariño, como escribe después Homero y otros, Angelo Policiano. Servían de letra... los versos de Marcial en este dístico foedere felici iungatur ut Hesperus austro. A te virgo petit ceston et ipsa Venus.

Una esfera o globo celeste que ceñía y atravesaba por medio una faja ancha y oblicua como el zodiaco, en que se veían solamente los dos signos vecinos de León y Virgo formados ambos de estrellas y retrato el primero del Príncipe y el segundo de la Señora infanta ... mirabase por bajo de él en la parte sujeta y correspondiente a los dos signos de león y virgo, que de ellos recibían influencias de unión y conformidad dos figuras de España y Austria a quien aquí había dado el pincel iguales adornos ... la letra era de Manilio, Coniuncta leoni regna ferunt summas partes et virginis esse.

These last hieroglyphs were placed next to the Infanta María Teresa represented as Concord (Fig. 61, no. 12). ${ }^{91}$ Hieroglyph 23 represents a young girl (María Teresa) wearing a fleurdelisée belt in the form of Venus's girdle, suggesting the happiness that would befall the alliance of the Austrian and Spanish Habsburgs. The motto is adapted from Martial (Epigrams, vi.93.8: 'A te Iuno petat ceston et ipsa Venus'). The correspondence between the words 'cestum' and 'cingulum' was established by Erasmus in his Adagia. ${ }^{92}$

Hieroglyph 24 is rather curious. Though María Teresa was born under the sign of Virgo, Baltasar Carlos was not born in Leo. The motto chosen from the Astronomica of Manilius probably led the author of the programme to exploit a good astral conjunction to predict unending happiness for both branches of the Habsburgs. As the lion is a prominent feature of the Spanish arms, it may have seemed appropriate to identify the young heir to the throne with Leo.*

88 See above, p. 181.

${ }^{89}$ See above, n. 50.

90 A. A. Atiya in Crusade, Commerce and Culture, London 1962, pp. 105-6, mentions that the French sources refer to the town as 'Cité d'Affrique'. Lançina's source is Nicolas Caussin, Polyhistor symbolicus, electorum symbolorum et parabolarum historicarum stromata..., Paris 1618.

91 Discussed above, p. 181.

92 Erasmus, Adagiorum, Proverbiorum Chiliadis Tertiae centuria prima, Cestum habent Veneris, xxxvi (Basle 1541, p.
669): 'Venerem adit atque ab ea cingulum gratiarum et amorum conciliatorem commodato petit' (paraphrasing Homer).

* I thank very much Elizabeth McGrath for comments that have contributed to add rigour and substance to the text. Without the help of my husband, Dr Andrés Zuker, I could not have imagined an English version of this work. I also thank Barbara Knowles and Diane Garrey of the Central Language Service of the University of Salamanca. 